\title{
TEMPEH DE FARELO DE SOJA
}

\section{ELY NAHAS}

Orientador: DR. RODOLPHO DE CAMARGO

\begin{abstract}
Dissertação apresentada à Escola Superior de Agricultura "Luiz de Queiroz", da Universidade de São Paulo, para obtenção do título de Mestre em Microbiologia Agrícola.
\end{abstract}

PIRACICABA

Estado de São Paulo - Brasil

Abril, 1978 
A meus pais,

à Maria Amālia, à Flāvia e ao Fābio. 
E com satisfação que agradeço a todas as pes soas e entidades que contribuiram para a realização deste tra balho:

Ao Prof. Dr. Rodolpho de Camargo, pela orienta ção e estímulo durante todo o decurso do mesmo.

Ao Prof. Dr. José Eduardo Dutra de Oliveira, pe las facilidades proporcionadas para a realização do ensaio biológico;

À Profa. Dra. Maria Amélia Chaib Moraes, pela participação e auxílio no desenvolvimento da parte experimen tal no setor de análise sensorial;

A Profa. Dra. Ruth dos Santos Garrutti, pelo planejamento da análise sensorial e facilidades no uso do res pectivo laboratório;

Aos colegas Profs. José F. Durigan, José F. Pe dras, José O. Machado, Manoel Victor F. Lemos, Pedro M. Laca va, Ruben Pablo Schocken e Sérgio N. Kronka, pelas valiosas sugestões.

Aos Srs. Antonio Luiz Sartori e Izaltino Rocha e Silva Filho e à Srta. Eliana Aparecida M. Ferreira, pelos auxílios prestados;

A Faculdade de Ciências Agrárias e Veteriná rias "Campus" de Jaboticabal, onde este trabalho foi realiza do;

Aos demais professores, colegas e pessoas que direta ou indiretamente contribuiram para a sua execução. 


\section{INDICE}

Pāgina

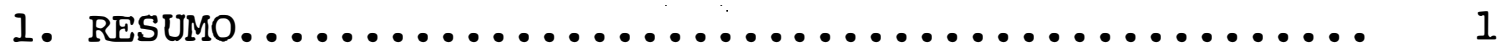

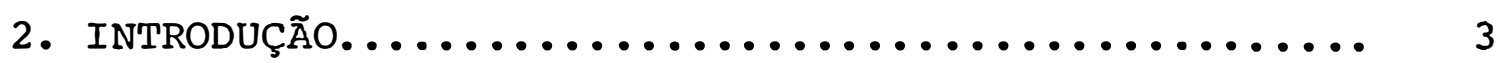

3. REVISÃO DE LITERATURA..................... 5

3.1. Torta e farelo de soja................. 5

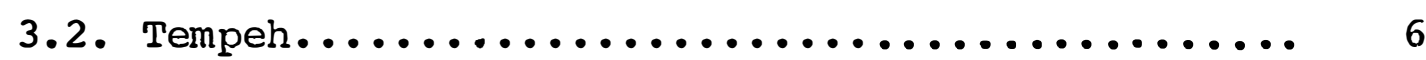

3.2.1. Tipo de materiais utilizados e seu pre paro.......................... 7

3.2.2. Espécies de fungos utilizadas......... 9

3.2.3. Inóculo........................ 10

3.2.4. Recipientes de fermentação........... 11

3.2.5. Temperatura e tempo de fermentação..... 12

3.2.6. Características bioquímicas e biológi

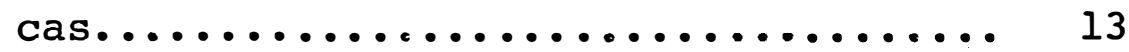

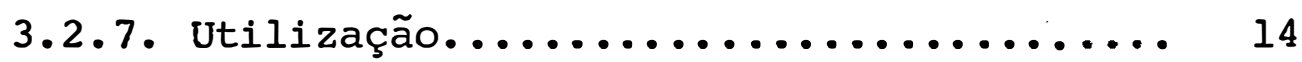

4. MATERIAL E METODOS........................ 16

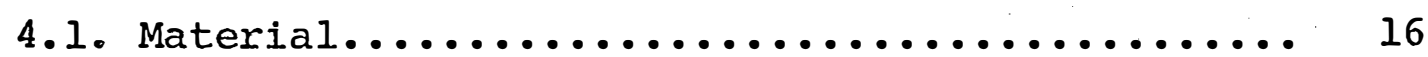

4.1.1. Farelo de soja tostado............ 16

4.1.2. Suplementos................... 16

4.1.3. Soja em grão.................... 17

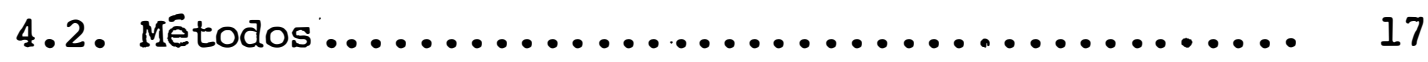

4.2.1. Procedimento tecnológico............ 17

4.2.1.1. Produção do tempeh de farelo de soja................. 17

4.2.1.2. Produção de tempeh de grãos de soja.................... 18

4.2.1.3. Tratamentos............... 18 
Pāgina

4.2.1.4. Desenvolvimento de $R$. oligospo rus no farelo adicionado dos diversos suplementos......... 19

4.2.1.5. Rendimento e perdas......... 19

4.2.2. Análises bioquímicas.............. 20

4.2.2.1. Material para as análises.... 20

4.2.2.2. Umidade................. 20

$4.2 .2 .3 . \mathrm{pH} \ldots \ldots \ldots \ldots \ldots \ldots \ldots \ldots . \ldots . \ldots . . \ldots 20$

4.2.2.4. Cinzas................... 20

4.2.2.5. Matéria graxa............ 20

4.2.2.6. Proteína total............ 21

4.2.2.7. Proteína verdadeira......... 21

4.2.2.8. Proteína dispersa.......... 22

4.2.2.9. Fibra crua............... 22

4.2.2.10. Carboidratos............... 22

4.2.3. Avaliação biológica da qualidade da pro

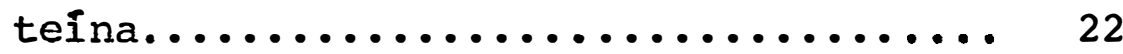

4.2.3.1. Coeficiente de utilização prọ téica (CUP) ................. 22

4.2.4. Anālise sensorial................ 23

4.2.5. Análise estatística............... 24

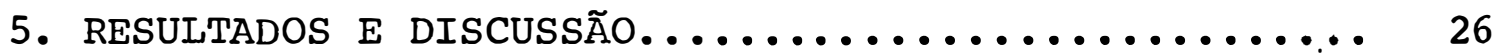

5.1. Tempeh de farelo de soja................ 26

5.2. Rendimento, $\mathrm{pH}$ e umidade................ 33

5.3. Composição centesimal................. 36

5.4. Valor nutritivo...................... 40

5.5. Anālise sensorial.................... 43

6. CONCLUSÕES.............................. 45

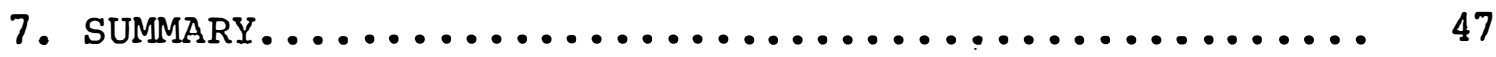

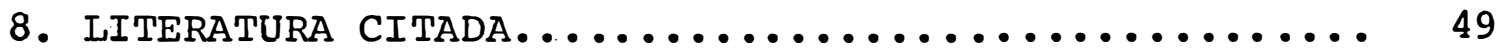


1. RESUMO

Verificou-se a possibilidade de fermentação do farelo de soja, subproduto da indústria de óleo, a fim de se produzir um produtc similar ao tempeh, alimento oriental, ori ginalmente elaborado a partir de grãos de soja cozidos. O processo tecnológico mostrou a necessidade de adição ao fare lo de soja de no mínimo $30 \%$ de um suplemento de carboidrato, dos quais foram utilizados farinha de mandioca, fubá e farelí nho de arroz, de 3,5\% de ácido cítrico a fim de reduzir o $\mathrm{pH}$ para 4,5 e de $150 \%$ de água destilada do peso da mistura fare lo-suplemento. Após fermentação, que foi conduzida em placas de Petri por meio de Rhizopus oligosporus, à temperatura de $35-37^{\circ} \mathrm{C}$, por 24 horas, obteve-se um produto que se chamou de tempeh de farelo de soja (TFS), que se assemelhou a um bo lo compacto, de coloração branca e de odor agradável, de frú tas, algo alcoólico.

Analisou-se o TFS, em cotejo com o tempeh e o farelo de soja, quanto às características bioquímicas, bioló gicas e sensoriais. Os resultados mostraram um produto com igual teor de proteína total, menor teor de óleo e quantida des superiores de fibra crua, cinzas e carboidratos que o tempeh. A fermentação não variou a composição centesimal do farelo, exceto para matéria graxa, e nem melhorou o teor de 
proteína crua quando se comparou o TFS com o farelo, porém, aumentou de 3,3 - 3,5 vezes o teor de proteína dispersa indi cando uma melhoria da digestibilidade do TFS. 0 coeficiente de utilização protéica não foi alterado pela fermentação, po rém se mostrou equivalente ao padrão de caseína e superior ao tempeh. A análise sensorial revelou que o TFS é de aceitação regular, à semelhança do tempeh. 
2. INTRODUÇÃO

Ao se consultar a literatura sobre nutrição, ve rifica-se que inúmeros problemas são levantados, em todas as partes do mundo, ressaltando as diversas formas de conseqüên cias de uma alimentação deficiente ou desequilibrada. Dentre essas conseqüências, a mais grave está na necessidade de se satisfazer os requerimentos protéicos, principalmente de crianças dos seis meses aos seis anos e de mulheres em gestą ção ou lactação. A deficiência de proteínas constitui o fa tor mais importante da mortalidade infantil, acarretando tam bém retardamento no desenvolvimento físico e mental, predis pondo crianças e adultos às enfermidades e tornando adultos incapacitados ou com baixa produtividade para o trabalho.

Com base nesses aspectos, inúmeros países vem se esforçando em encontrar soluções no sentido de resolver os vários problemas nutrimentais e melhorar os padrões alimenta res de diversas partes do mundo, inclusive no Brasil. Para isso, programas integrados são desenvolvidos sob a égide de organismos internacionais como UNICEF (United Nations Interna tional Children's Fund), FAO (Food and Agriculture Organiza tion) e WHO (World's Health Organization) e nacionais como PRONAN (Programa Nacional de Alimentação e Nutrição, instituí do a 30/03/1973), com a ajuda, ainda, de diversas fundações particulares. 
Devido aos fatores limitantes de se conseguir proteína de origem animal, a pesquisa está dirigida para a b tenção de proteínas vegetais, de baixo custo, particularmente de resíduos das sementes de plantas oleaginosas, como soja, amendoim, algodão, côco, gergelim e girassol.

Um dos resíduos mencionados que parece bastan te promissor, tanto pela sua riqueza em nutrientes como pela necessidade de pesquisas para seu melhor aproveitamento, é o farelo de soja, subproduto da indústria de óleo. A produção de soja em 1976 foi da ordem de aproximadamente $11.227 \mathrm{mil} \mathrm{t}$, no Brasil (BRASIL. Fundação IBGE, 1976). Deste total 80\%, aproximadamente, constituem o resíduo da extração de óleo e que é utilizado, especialmente, na alimentação de animais.

o processamento da soja (grãos) por fermenta ção microbiana dá um alimento conhecido na Indonésia por tempeh. À semelhança desse produto que é fermentado para pro duzir tempeh, inúmeros outros alimentos são produzidos por fermentação microbiana, em várias partes do mundo, a partir dos mais diferentes substratos, como amendoim, trigo, arroz, cidra, leite, milho, etc.

Tendo em vista as qualidades nutritivas da so $j a$, as vantagens que o processo fermentativo de preparo desse alimento oferece, pretendeu-se, nesse trabalho, avaliar os efeitos desse método sobre a elaboração de tempeh de farelo de soja, subproduto da indústria de óleo, bem como caracteri zar suas qualidades bioquímicas, nutrimentais e organoléticas. 
3. REVISÃO DE LITERATURA

\subsection{Torta e farelo de soja}

Segundo ROHR (1973), as tortas ou farelos são produtos resultantes da extração de óleo, possuindo em geral reduzido teor de óleo e com seu componente protéico ligeira mente acidificado. A diferenciação entre esses produtos, ain da segundo o mesmo autor, baseia-se no tipo de extração: na torta, a extração é realizada por prensas mecânicas e no fare lo é por solvente com posterior moagem. Uma variação nesses processos, verificada na indústria, consiste na extração da maior quantidade de óleo por prensas, e depois por solvente.

O teor de proteína varia de 40,5 - 49,0\% (PION, s/d; ORR e ADAIR, 1967) ou, ainda, de 40 a 55\% (COSTA et alii, 1976). O teor de aminoácidos da torta de soja (PION, s/d) aproxima-se ao da soja em grão (PION, 1973; EVANS e BANDEMER, 1967) apresentando, portanto, as mesmas deficiências nos ami noácidos sulfurados.

o valor nutritivo da soja decorre de suas pro teínas, por serem muito semelhantes às animais e humanas (BRASIL. Ministério do Interior (b), s/d). Quanto ao farelo da soja, o seu alto teor de proteína de boa qualidade (COSTA et alii, 1976) tornam-no um alimento bastante promissor no sentido de satisfazer as necessidades protéicas. 
Devido ao aquecimento, tanto na extração do óleo por prensas como por solvente, ocorre desnaturação, apre sentando assim menor teor de proteína solúvel que a soja em grão (BELTER e SMITH, 1952). Porém, o aquecimento da soja no processo de extração melhora o valor protéico, porque ocorre destruição de fatores antinutricionais como o inibidor de tripsina e a atividade de urease (van BUREN et alii, 1964). Segundo COSTA et alii (196\%), no processo de extração há rea lizạção da tostagem do farelo, onde se conjuga tempo-tempera tura-umidade com a finalidade estrita de inibir fatores anti nutricionais que ocorrem na soja.

3.2. Tempeh

Produto de grande importância para a Indonésia e Surinam e de relativa importância para a Holanda, constitui o resultado da fermentação fúngica dos grãos de soja previa mente cozidos. Seu valor nutritivo tem dado ensejo à realiza ção de inúmeras pesquisas em diversos países do globo, como Estados Unidos, Japão, Indonésia, Holanda e outros, inclusive o Brasil.

o método original do preparo do tempeh na Indo nésia consta em linhas gerais do seguinte (STEINKRAUS et alii, 1960; DJIEN e HESSELTINE, 1961; HESSELTINE, 1965): a soja é imersa em água fria, corrente ou não, por uma noite ou em água quente por tempo curto. A casca dos grãos, imersos na água, é removida manualmente ou através da pisadura com os pés descalços, de onde fica flutuando e é eliminada. A se guir, a soja é fervida por cerca de meia hora a fim de amo lecê-la e destruir os microrganismos contaminantes. A água de cozimento é eliminada e então a soja é espalhada em cama das finas para evaporação da ãgua da superfície. A soja as sim seca é inoculada através de raspagens da superfície do produto já fermentado e posteriormente mantida envolta em 
folhas de banana para fermentar em lugar quente. O tempeh re sultante é um bolo compacto que pode ser cortado, seco ou não, assado, cozido ou frito.

Os métodos utilizados em laboratório (e moder namente) variam de autor para autor. O fluxograma apresenta do na Fig. 1, adatado de HESSELTINE e WANG (1967) menciona as etapas gerais do processo.

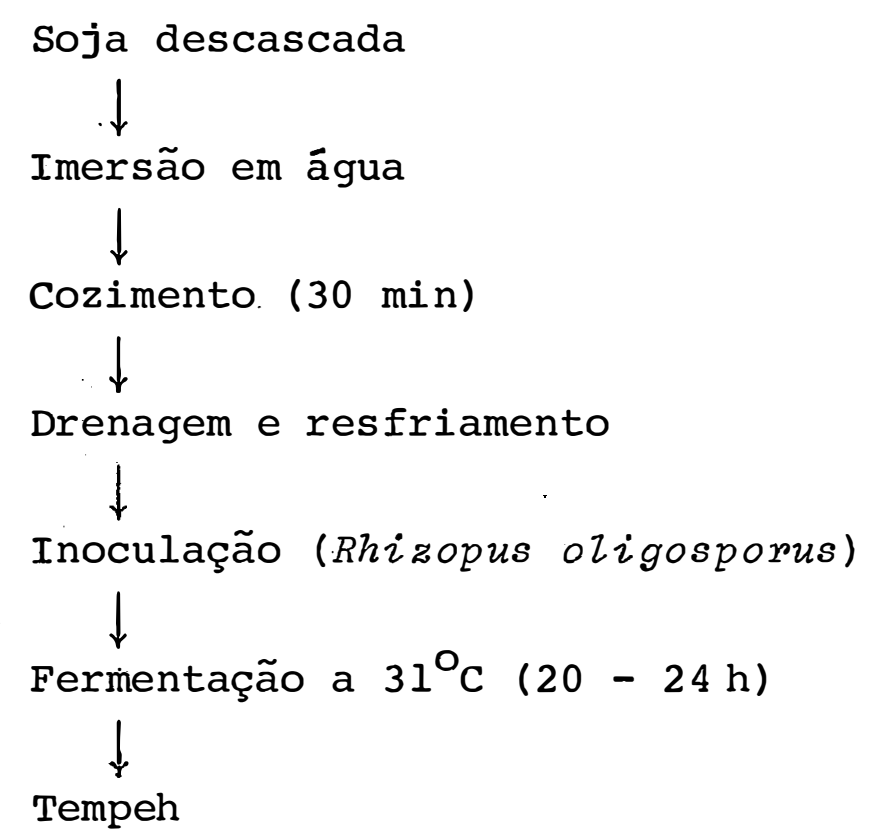

Fig. 1 - Fluxograma de produção do tempeh (HESSELTINE e WANG, 1967).

Com base na literatura consultada, pode-se sub dividir o processo geral de produção de tempeh em etapas que serão apresentadas a seguir:

3.2.1. Tipo de materiais utilizados e seu preparo

De modo geral, a soja em grão constitui o mate rial predominante para o preparo do tempeh, então denominado tempeh kedelee $(k e d e l l e=$ qrão de soja). Porēm a literatura menciona, ainda, o uso da torta de côco (van VEEN e SHAEFER, 1950) e de copra (HESSELTINe, 1965). 
Foi empregada a soja das variedades Araçatuba (LEITÃo et alii, 1967/6்8; CAMARGO, 1969), Clark (HACKLER et alii, 1964; STEINKRAUS et alii, 1965), Harosoy (MURATA et alii, a167), Hawkeye (SHITH et alii, 1964; MARTINELLI e HESSELTINE, 1964) ou Seneca (STEINKRAUS et alii, 1960), sendo que os grãos podiam ser utilizados inteiros, quebrados em 6 a 8 peda ções ("grits") ou na forma de lascas ("chips") (SMITH et alii, 1964). À soja em grãos, previamente selecionada e lavada, é adicionada água na proporção, respectivamente, de $1: 3$ e ácí do lático no teor de 1\% (STEINKRAUS et alii, 1960; ROELOFSEN e TALENS, 1964) ou até pH 4,0 (LEITÃo et alii, 1967/68), man tendo-se assim por uma noite ou 24 horas. HACKLER et alii (1964) incluiram uma fase anterior compreendida pela secagem da soja em estufa com circulação de ar quente, a $104^{\circ} \mathrm{C}$ por 10 min, seguida de moagem para a retirada da casca. MURATA et alii (1967) utilizaram ácido acético no teor do 0,25\%, em vez de ácido lático, com posterior fervura por 2 horas, segui da de imersão em solução quente de ácido acético a 0,25\% por 5 min.

Após o período de imersão, a solução ácida è drenada, procede-se ao descascamento dos grãos, operação que é facilitada se realizada em recipiente com água corrente ou não de modo que a casca, que flutua, é eliminada. Segundo ROELOFSEN e TALENS (1964), após a fase de imersão, a soja. é fervida por $10 \mathrm{~min}$, seguindo-se a retirada da água e descasca mento.

Retirada a casca, a soja é fervida a $100^{\circ} \mathrm{C}$; em pregando-se a mesma solução de ácido lático, pelo período de tempo de $90 \mathrm{~min}$ (STEINKRAUS et alii, 1960; HACKLER et alii, 1964 ) ou $40 \mathrm{~min}$ (LEITÃO et alii, 1967/68). A seguir, elimi na-se a solução de fervura e deixa-se esfriar os grãos, esten didos sobre toalhas de modo a permitir a secagem superficial, até a temperatura baixar a 31 ou $37^{\circ} \mathrm{C}$, quando serão inocula dos. A secagem pode ser realizada, também, segundo ROELOFSEN e TALENS (1964), em estufa a $60^{\circ} \mathrm{C}$ até que a umidade anterior 
de 64\% diminua para 55\%. HACKLER et alii (1964) procederam ao resfriamento rápido dos grãos, mantendo-os a $5^{\circ} \mathrm{C}$.

WANG e HESSELTINE (1966) e WANG et alii (1968)

obtiveram, respectivamente, tempeh de trigo e de uma mistura de trigo com soja, a partir de produtos lavados e quebrados; o tempo de fervura foi de 12 min para o trigo e de 25 min pa ra a soja.

3.2.2. Espécies de fungos utilizadas

DJIEN e HESSELTINE (1961) mencionam que ao mㅌ nos quatro espécies podem ser utilizadas para produzir tempeh: Rhizopus stolonifer, R. oligosporus, R. oryzae e R. arrhizus. HESSELTINE (1965) acrescenta mais duas espécies à lista ante rior, $R$. formosaensis e. $R$. achlamydosporus, porém, menciona que, embora outros fungos pudessem ser isolados de tempeh, ape nas Rhizopus produziría esse produto, sendo $R$. oligosporus a principal espécie usada na Indonésia.

Apesar disso, STEINKRAUS et alii (1965) obtive ram as mesmas mudanças químicas, porém não as mesmas caracte rísticas organoléticas, com a utilização do fungo Neurospora sp, isolado de um alimento indonésio chamado "ontjom", para fermentação de soja. DIOKNO PALO e PALO (1968) testaram, ain da, duas espécies de fungo filipinas, Rhizopus sp A-12680 e Cunninghamella elegans A-12679 com R. stolonifer, concluindo que a primeira espécie produz um tempeh mais compacto, com me lhor "flavor" e maior crescimento fúngico que as demais.

van VEEN e SHAEFER (1950) mencionam $R$. oryzae como a espécie utilizada na ilha de Java. Na Holanda, ROELOFSEN e TALENS (1964) empregaram a espécie $R$. arrhizus. As de mais citações bibliográficas mencionam a utilização da espé cie $R$. oligosporus NRRL 2710, isolada de tempeh da Indonésia. CAMARGO 1969) estudou, com base na atividade proteolítica, 43 variedades de fungos, concluindo que $R$. oligosporus SAITO foi a única espécie que apresentou resultados positivos para to dos os ensaios realizados. 


\subsubsection{Inóculo}

o tipo e a quantidade de inóculo são variáveis. Os tipos utilizados são os seguintes: A) meio de cultura es porulado, liofilizado e pulverizado (STEINKRAUS et alii, 1960 e 1965; HACKLER et alii, 1964); B) tempeh seco ou liofiliza do e pulverizado (ROELOFSEN e TALENS, 1964; MURATA et alii, 1967); C) suspensão de esporos obtida pela adição de água destilada ao meio de cultura inclinado e esporulado (HESSELTINE, 1965; MARTINELLI e HESSELTINE, 1964; WANG e HESSELTINE, 1966). Embora a diversidade de tipos de inóculo utilizada pe los autores, o tipo $C$ tem sido empregado em cultivos em esca la de laboratório e os tipos A e B, em maior escala. A quan tidade de inóculo variou do seguinte modo: 1\% do peso da soja crua de (A) (MURATA et alii, 1967); o inóculo B foi utilizado nos teores de $2 \mathrm{~g}$ (HACKLER et alii, 1964) ou 3g (STEINKRAUS et alii, 1965) por $\mathrm{kg}$ de soja crua e $\mathrm{lg} / \mathrm{kg}$ de soja cozida (STEINKRAUS et alii, 1960); o inóculo (C) foi empregado na quantidade do $2 \mathrm{ml} / 100 \mathrm{~g}$ de soja (MARTINELLI e HESSELTINE, 1964), 0,5 ml/35g de trigo (WANG e HESSELTINE, 1966) ou $\mathrm{lg} / 40 \mathrm{~g}$ de soja (CAMARGO, 1969).

Após a inoculação, procede-se à mistura para distribuição do fungo pelos grãos de soja cozida.

Para preparar o meio de cultura, STEINKRAUS et alii (1960) utilizaram $100 \mathrm{~g}$ de farinha de trigo umidecida com $300 \mathrm{ml}$ de uma solução ácida (onde foi previamente imersa soja), esterilizada a $120^{\circ} \mathrm{C}$ por $20 \mathrm{~min}$. O fungo semeado nes se meio de cultura é mantido a $37^{\circ} \mathrm{C}$ por 7 dias (com o que ob tiveram esporulação pesada), sendo posteriormente liofilizado e moído (20 mesh). Uma variação desse método foi utilizada por STEINKRAUS et alii (1965), apresentada no fluxograma da Fig. 2. 


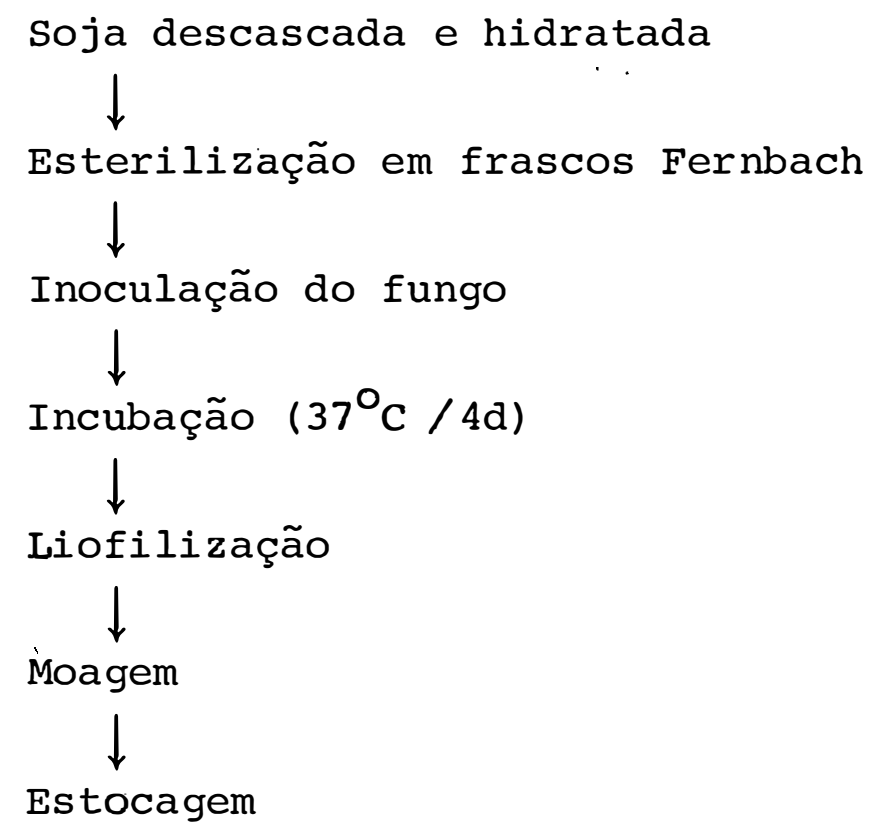

Fig. 2 - Produção de inóculo de $R$. oligosporus, segundo STEINKRAUS et alii (1965).

\subsubsection{Recipientes de fermentação}

Para a produção de um bom tempeh, há necessị dade de um perfeito controle da aeração: excesso de aeração favorece a esporulação, o que é indesejável; com falta de aeração, o fungo não se desenvolve. Esses aspectos tem leva do os pesquisadores a tentarem as condições ótimas de aeração. Em escala de laboratório, WANG e HESSELTINE (1966), HESSELTINE (1965) e CAMARGO (1969) relataram o uso de placas de Petri como recipiente de fermentação, desde que se tome o cuidado de deixar um mínimo de espaço vazio entre a soja e a tampa da placa (CAMARGO, 1969). Outros tipos de recipientes menciona dos pela bibliografia, bandejas de aço inoxidável, de plástí co ou de madeira e sacos plásticos foram utilizados para pro dução de tempeh em maior quantidade, dependendo das possibili dades e das finalidades do trabalho. STEINKRAUS et alii (1960) utilizaram bandejas metálicas com furos de aproximada mente $3,0 \mathrm{~mm}$, a cada $5,0 \mathrm{~cm}$, no fundo e tampa; HACKLER et alii 
(1964) usaram bandejas de tampa metálica de 25,4 x 35,6 x 6,4 cm e $2,54 \mathrm{~cm}$ de profundidade, ou então, bandejas com fundo de ma Tha de 35,6 x 79,3 x 1,27 cm; ROELOFSEN e TALENS (1964) emprega ram caixas de polietileno de $10 \times 20 \times 3 \mathrm{~cm}$, com tampa bem ajustada, com 6 furos de $2 \mathrm{~mm}$ de diâmetro na tampa e fundo; MARTINELLI e HESSELTINE (1964), além das bandejas metálicas, utilizaram sacos plásticos $(20 \times 38$ e $13 \times 21 \mathrm{~cm})$ e tubos plásticos (10 cm de diâmetro) sendo a perfuração recomendada de 0,6 mm de diâmetro apresentando a distância de $1,3 \mathrm{~cm}$ en tre centros; STEINKRAUS et alii (1965) empregaram recipientes para $3 \mathrm{~kg}$ de soja com $35 \times 81 \times 13 \mathrm{~cm}$, cobertos com papel en cerado; ainda, CAMARGO (1969) utilizou bandeja com fundo de Eucatex e divisões de madeira, de $44 \times 34 \times 6 \mathrm{~cm}$, tendo 5 di visões iguais, com capacidade de $500 \mathrm{~g}$ de soja cada.

\subsubsection{Temperatura e tempo de fermentação}

A temperatura utilizada, conforme literatura consultada, para fermentação da soja variou de 27 a $37^{\circ} \mathrm{C}$ o que implicou numa amplitude de tempo para que o tempeh estí vesse pronto, entre 18 e 24 horas. STEINKRAUS et alii (1960) utilizaram a temperatura de $37^{\circ} \mathrm{C}$ por 24 horas e HACKLER et alii (1964) empregando a mesma temperatura de fermentação, ob tiveram uma redução do tempo para 18 horas, quando foi contro lado o nível de umidade relativa em $80 \%$. MURATA et alii (1967) afirmaram ter obtido um produto mais palatável com 48 horas de fermentação a $37^{\circ} \mathrm{C}$. HESSELTINE (1965), WANG e HESSELTINE (1966), WANG et alii (1968) e CAMARGO (1969) utili zaram temperaturas entre $31-32{ }^{\circ} \mathrm{C}$, deixando fermentar por 20 a 24 horas. ROELOFSEN e TALENS (1964) empregaram um procedi mento diferente, qual seja manter os recipientes de fermenta ção por 24 horas a $27^{\circ} \mathrm{C}$ e depois invertê-los e deixá-los por mais 24 horas.

Segundo MARTINELLI e HESSELTINE (1964), para produção de tempeh foram necessárias 80 horas a $25^{\circ} \mathrm{C}, \quad 26$ a 
$28^{\circ} \mathrm{C}$ e $22-24$ horas a 31 e $37^{\circ} \mathrm{C}$. Temperaturas superiores a $37^{\circ} \mathrm{C}$ favorecem o crescimento de bactérias contaminantes. A $31^{\circ} \mathrm{C}$, a soja deveria permanecer por $15-16$ horas na estufa e depois ser retirada para completar. a fermentação à temperatü ra ambiente, porque durante o desenvolvimento do fungo a tem peratura se eleva a 47 ou $49^{\circ} \mathrm{C}$ (STEINKRAUS et alii, 1960 e MARTINELLI e HESSELTINE, 1964) com perigo da inibição do fungo.

\subsubsection{Características bioquímicas e biológicas}

Com relação às transformações que ocorrem. du rante a fermentação, verifica-se um aumento no teor de fibra (STEINKRAUS et alii, 1960 e MURATA et alii, 1967) e de sólí dos solúveis (STEINKRAUS et alii, 1960 e HESSELTINE, 1965). De um modo geral, o teor de nitrogênio não varia (STEINKRAUS et alii, 1965; WANG e HESSELTINE, 1966; MURATA et alii, 1967; LEITÃO et alii, 1967/68; CAMARGO, 1969). Por outro lado, ve rifica-se uma forte ação proteolítica (HESSELTINE, 1965; WANG e HESSELTINE, 1966), tendo o teor de aminoácidos livres aumen tado de 1 a 85 vezes (MURATA et alii, 1967). Ocorre também forte ação lipolítica evidenciada pelo aumento no teor de áci dos graxos (WAGENKNECHT et alii, 1961; MURATA et alii, 1967; LEITÃo et alii, 1967/68). Com relação às vitaminas, há um aumento no teor de niacina e riboflavina (ROELOFSEN e TALENS, 1964; WANG e HESSELTINE, 1966; MURATA et alii, 1967) e de ví taminas $\mathrm{B}_{6}$, ácido nicotínico e ácido pantotênico (MURATA et alii, 1967). De modo geral, o teor de tiamina ou se reduziu ou não aumentou.

Comparando o valor nutritivo do tempeh, WANG et alii (1968) confirmaram uma melhoria no crescimento de ra tos alimentados com esse produto e no "PER", enquanto que SMITH et alii (1964) observaram redução no peso e no "PER" e HACKLER et alii (1964) e CAMARGO (1969) não obtiveram varia Ção nessas características. 
Os problemas de digestibilidade da soja são su perados pelo produto fermentado, como ressaltado por HESSELTINE (1965), pelo fato do tempeh ter sido consumido por prisio neiros de guerra que mesmo sofrendo de disenteria e edemia nu tricional conseguiram assimilar por este modo a soja.

\subsubsection{Utilização}

Segundo STEINKRAUS et alii (1960), o tempeh fresco e cru tem um odor limpo e agradável e um "flavor" seme lhante a queijo. O produto frito possui um "flavor" de amên doas aceitável. A esse respeito, CAMARGO (1969) concluiu, através de análise sensorial, pela aceitabilidade do tempeh, sendo que a variedade de soja Hardee apresentou melhor textu ra entre as outras variedades ensaiadas.

Como mencionam van VEEN e SHAEFER (1950), O tempeh não é consumido cru. Pode ser cortado, seco ou não, $\underline{\mathrm{c}}$ zido ou frito (DJIEN e HESSELTINE, 1961). Porém, como o pro duto é perecível, deve ser consumido logo após a fermentação ou, então, conforme assinala HESSELTINE (1965), pode ser lio filizado ou aquecido levemente para destruir o fungo ou enzí mas e então congelado. Nesse sentido, van VEEN e SHAEFER (1950) sugerem aquecimento a $150^{\circ} \mathrm{C}$ por aproximadamente $10 \mathrm{~min}$.

A forma mais comum de consumir o tempeh, segun do o seu país de origem, é frito. Para isso STEINKRAUS et alii (1960 e 1965), ao realizarem a análise sensorial, corta ram o tempeh em fatias, salgaram em uma solução de sal a 10\% e fritaram em excesso de óleo a $190^{\circ} \mathrm{C}$ até obter leve colora ção castanha e encrespamento. CAMARGO (1969) analisou o tempeh produzido de diversas variedades de soja, tendo também empregado material cortado em fatias o qual foi frito em óleo de milho até coloração amarelo-dourada, com pequena adição de sal.

STEINKRAUS et alii (1965) mencionam que na In donésia o tempeh desidratado ( 2 - $4 \%$ umidade) pode ser usado 
frito ou cortado em cubos, misturado com vegetais e consumido com uma sopa onde ele se reidrata completamente em menos de $30 \mathrm{~min}$ a $100^{\circ} \mathrm{C}$. Esses autores obtiveram 0 tempeh desidratado em $1 / 2$ - 2 horas colocando cubos do material de $2,5 \mathrm{~cm}$ de la do em estufa com circulação forçada de ar, a $93^{\circ} \mathrm{C}$. Mencionam tambēm que essa última forma de consumo não foi aceita pelo povo norte-americano que preferiu misturá-lo com 25\% de arroz ou $50 \%$ de milho doce desidratado, na forma de sopa.

Finalmente, ILJAS et alii (1970) mostraram que não hã diferença na aceitação do tempeh conservado por conge lação, enlatamento ou desidratação. Para esses ensaios, es ses autores fritaram o material cortado em fatias, após salga por imersão em salmoura a 5\%, em óleo de amendoim, a $177^{\circ} \mathrm{C}$ por $4 \mathrm{~min}$. 
4. MATERIAL E MÉTODOS

\subsection{Material.}

\subsubsection{Farelo de soja tostado}

E o produto resultante da extração de óleo dos grãos de soja; com posterior moagem (ROHR, 1973). o farelo de soja tostado ou, simplesmente, farelo (denominação também adotada neste trabalho) foi adquirido no Departamento de zoo tecnia da Faculdade de Ciências Agrárias e Veterinárias (FCAV) do "Campus" de Jaboticabal. Para a sua fermentação, o farelo foi inspecionado para eliminação de gravetos, grumos e outras sujidades e para as análises químicas foi moído para se obter uma fração granulométrica inferior a $1 \mathrm{~mm}$ (AOAC, 1965).

\subsubsection{Suplementos}

Foram utilizados farinha de mandioca, fubá e farelinho de arroz, adquiridos no comércio local. As especí ficações dos dois primeiros foram normalizadas pelo Decreto no 52504, de 28 de julho de 1970, publicado no Diário Oficial do Estado de São Paulo (ano LXXX - no 142 - p. 2) em 19 de agosto de 1970: 
a) Farinha de mandioca: produto obtido pela li. geira torração da raladura das raízes da mandioca (Manihot utilissima) previamente descascadas, lavadas e isentas do ra dical cianeto.

b) Fubá de milho ou fubá: produto obtido pela moagem do grão de milho (Zea mays L.) desgerminado ou não.

c) Farelinho de arroz: produto resultante da industrialização do arroz, nas operações de polimento e brü nimento (BRASIL. Ministério do Interior (a) $\mathrm{s} / \mathrm{d}$ ).

\subsubsection{Soja em grão}

Variedade Santa Rosa, obtida no Departamento de Fitotecnia da F.C.A.V. "Campus" de Jaboticabal.

\section{2. $\underline{\text { Métodos }}$}

\subsubsection{Procedimento tecnológico}

4.2.1.1. Produção de tempeh de farelo de soja

Para fermentação do farelo de soja seguiu-se a seguinte marcha: ao farelo adicionou-se $30 \%$ em peso do suple mento e homogeneizou-se bem, obtendo-se assim uma mistura que foi adicionada a uma solução-suspensão de água destilada (vô lume de $150 \%$ do peso da mistura) contendo 3,5\% de ácido cítrí co do peso da mistura e esporos do fungo Rhizopus oligosporus SAITO (NRRL 2710). A suspensão de esporos e a quantidade de inóculo foi obtida, com algumas modificações, conforme MARTI NELLI e HESSELTINE (1964) do seguinte modo: a uma cultura do fungo, em meio de malte inclinado, com 5 - 7 dias de idade, adicionou-se $4 \mathrm{ml}$ de solução esterilizada de tween a 0,001\%; a seguir, procedeu-sè à raspagem dos esporos do fungo com al ça de platina, obtendo-se a suspensão respectiva a qual foi utilizada para $100 \mathrm{~g}$ de mistura. 
Após a adição da mistura à solução-suspensão de água destilada, procedeu-se ao seu revolvimento com uma co lher, obtendo-se uma massa solta, a qual foi acondicionada de maneira frouxa, sem compactação, em placas de Petri de $9 \mathrm{~cm}$ de diâmetro e levada à estufa para fermentação a $35-37^{\circ} \mathrm{C}$, por 24 horas.

O uso de suplementos, ácido cítrico e água des tilada com o farelo serão discutidos no capítulo corresponden te.

4.2.1.2. Produção de tempeh de grãos de soja

Utilizou-se a técnica de HESSELTINE et alii (1966), que constou do seguinte: aos grãos de soja descasca dos e a seguir lavados adicionou-se água na proporção de $1: 5$, mantendo-se por uma noite; posteriormente, foram feitas novas lavagens e a soja foi cozida na mesma proporção de água por $30 \mathrm{~min} ;$ após esse período de tempo, a água foi eliminada e a soja vertida em panos esterilizados para eliminar o excesso de água; quando fria, à temperatura de $35-40^{\circ} \mathrm{C}$, foi inocula da e acondicionada em placas de Petri para fermentação, con forme técnica descrita em 4.2.1.1. O período de fermentação, nesse caso, foi de aproximadamente 20 horas.

\subsubsection{Tratamentos}

Com base no proposto neste trabalho, foram es tabelecidos os seguintes tratamentos: 


\begin{tabular}{|c|c|c|}
\hline Ordem & Denominação adotàda & Tratamento \\
\hline 1 & Farelo & $\begin{array}{l}\text {-farelo de soja tostado (con } \\
\text { trole I) }\end{array}$ \\
\hline 2 & Farelo tratado & $\begin{array}{l}\text {-farelo de soja processado con- } \\
\text { forme } 4.2 .1 .1 . \text {, porém não ino } \\
\text { culado (Controle II). }\end{array}$ \\
\hline 3 & Tempeh & $\begin{array}{l}\text {-grãos de soja tratados confor } \\
\text { me 4.2.1.2. - tempeh de grãos } \\
\text { de soja (controle III) }\end{array}$ \\
\hline 4 & T. mandioca & $\begin{array}{l}\text {-farelo de soja suplementado } \\
\text { com } 30 \% \text { de farinha de mandio } \\
\text { ca, processado conforme 4.2.1.1. }\end{array}$ \\
\hline 5 & T. fubā & -idem, idem com fubā \\
\hline 6 & T. arroz & $\begin{array}{l}\text {-idem, idem com farelinho } \\
\text { arroz }\end{array}$ \\
\hline
\end{tabular}

4.2.1.4. Desenvolvimento de $R$. oligosporus no farelo adicionado dos diversos suple mentos

Com o objetivo de obter alguns dados sobre 0 desenvolvimento de $R$. oligosporus sobre o farelo com e sem su plementação, foram medidos $\mathrm{O} \mathrm{pH}$ e a temperatura a intervalos de 10 horas ou seja, nos tempos $0-10-20-30$ e 40 horas.

4.2.1.5. Rendimentos e perdas
o rendimento foi calculado com base no peso inicial de $100 \mathrm{~g}$ de farelo suplementado, farelo tratado ou ainda de soja respectivamente, e o peso final após fermenta ção. As perdas, em porcentagem, durante a fermentação, foram anotadas, pesando-se o conteúdo das placas de Petri antes: e após a fermentação. 


\subsubsection{Anālises bioquímicas}

\subsubsection{Material para as análises}

Após fermentação, o material foi seco em estu fa com circulação forçada de ar, a $60-70^{\circ} \mathrm{C}$, por uma noite. A seguir, triturado de modo a obter-se granulometria inferior a $1 \mathrm{~mm}$ (AOAC, 1965) e guardado em frascos herméticos.

\subsubsection{Umidade}

Foi determinada segundo técnica da AOAC (1965), em que $5 \mathrm{~g}$ do material, acondicionados em cartuchos de papel de filtro, foram secos em estufa a $100-105^{\circ} \mathrm{C}$ até peso cons tante.

\section{$4 \cdot 2 \cdot 2 \cdot 3 \cdot \mathrm{pH}$}

Utilizou-se o processo eletrométrico recomenda do pela AOAC (1965) em que $10 \mathrm{~g}$ do material foram adicionados a $100 \mathrm{ml}$ de água destilada com agitação esporádica por $30 \mathrm{~min}$ e posterior descanso por $10 \mathrm{~min}$; $0 \mathrm{pH}$ foi determinado no per colado, utilizando-se pH metro Horiba D 5.

\subsubsection{Cinzas}

De acordo com a $A O A C$, incinerou-se $2 \mathrm{~g}$ do mate rial seco em mufla, à temperatura de $550-600^{\circ} \mathrm{C}$ por 6 horas.

\subsubsection{Matéria graxa}

Foi utilizado o método recomendado pela AOAC (1965), segundo o qual $5 \mathrm{~g}$ de material seco (ver item 4.2.2.2.), contidos em cartucho de papel de filtro S \& S 597 de $15 \mathrm{~cm}$ de diâmetro, foram colocados em extrator de Soxhlet, por 6 horas; o teor da matéria graxa foi calculado com base na diferença de peso do balão de Soxhlet, antes e depois da extração. 


\subsubsection{Proteína total}

Foi determinada pelo método semi-micro kjeldahl, adaptado por SARRUGE e HAAG ( $\mathrm{s} / \mathrm{d}$ ) e que constou do seguinte: $0,1 \mathrm{~g}$ do material desengordurado foi tratado com $7 \mathrm{ml}$ da mis tura digestora $(3,6 \mathrm{~g}$ de selenito de sódio, 4,0 g de sulfato de cobre, 4,8 g de sulfato de sódio dissolvidos em $175 \mathrm{ml}$ de água destilada e $200 \mathrm{ml}$ de ácido sulfúrico) e, posteriormente, digerido em digestor infra-vermelho BUCHI, obtendo-se uma so lução límpida; essa solução foi tratada com $15 \mathrm{ml}$ de solução de $\mathrm{NaOH} 18 \mathrm{~N}$, em destilador BUCHI, recebendo-se o destilado em $10 \mathrm{ml}$ de uma solução a 2\% de ācido bórico-indicadores (so luções alcoólicas de verde bromocresol e vermelho de metila a $0,1 \%$, respectivamente), o qual foi posteriormente titulado com uma solução de $\mathrm{H}_{2} \mathrm{SO}_{4} 0,5 \mathrm{~N}$, obtendo-se a porcentagem de $\mathrm{N}$ na amostra.

O teor de proteína foi calculado multiplican do-se a \% de $\mathrm{N}$ pelo fator 6,25 (HART e FISHER, 1971).

\subsubsection{Proteína verdadeira}

Foi determinada pelo método do biureto (AOAC, 1965) que constou, em linhas gerais, do seguinte: 0,3 g de material desengordurado foi tratado com $20 \mathrm{ml}$ da solução de $\mathrm{NaOH} \quad 0,1 \mathrm{~N}$ e a seguir agitado por $15 \mathrm{~min}$; do sobrenadante to mou-se $1 \mathrm{ml}$ e tratou-se com $4 \mathrm{ml}$ do reagente de biureto $(1,5 \mathrm{~g}$ de sulfato de cobre e $6 \mathrm{~g}$ de tartarato duplo de sódio e potás siọ dissolvidos em $500 \mathrm{ml}$ de água destilada e adicionados a $300 \mathrm{ml}$ de hidróxido de sódio a 10\%); após $20 \mathrm{~min}$ de repouso, leu-se a absorbância em espectrofotômetro SPECTRONIC 80 a $540 \mathrm{~mm}$. As concentrações do material analisado foram obtidas a partir de uma curva padrão, previamente determinada, utili zando-se solução de albumina bovina na concentração ' ide $10 \mathrm{mg} / \mathrm{ml}$. 
4.2.2.8. Proteína dispersa

Utilizou-se a técnica da AOCs (1964) que cons tou, em resumo, em se suspender $20 \mathrm{~g}$ do material seco em $300 \mathrm{ml}$ de água destilada e agitar a $8.500 \mathrm{rpm}$ por $10 \mathrm{~min}$; a seguir, tomou-se $50 \mathrm{ml}$ do líquido e centrifugou-se por $10 \mathrm{~min}$ a $2.700 \mathrm{rpm}$; retirou-se, finalmente, $15 \mathrm{ml}$ do sobrenadante pa ra balão de kjeldahl e determinou-se o teor de proteína con forme descrito em 4.2.2.5.

\subsubsection{Fibra crua}

Utilizou-se o método da AACC (1969), em que $2 \mathrm{~g}$ de material desengorcurado foram digeridos com $200 \mathrm{ml}$ solução $\mathrm{H}_{2} \mathrm{SO}_{4} 1,25 \%$, seguindo-se filtração sob vácuo, através de pano (algodão); o material retido foi lavado com $200 \mathrm{ml}$ de solução $\mathrm{NaOH}(1,25 \%)$ e digerido nessa solução por mais 30 min; a se guir, filtrou-se através do cadinho de Gooch com camada fil trante de amianto; o cadinho foi seco em estufa a $100-105^{\circ} \mathrm{C}$ por $2 \mathrm{~h}$ e a seguir levado à mufla a $550-600^{\circ} \mathrm{C}$ por 2 horas. A fração fibra foi calculada com base na diferença de peso do cadinho, antes e depois da incineração.

\subsubsection{Carboidratos}

o teor de carboidratos foi calculado com base na diferença entre a soma dos teores de cinza, matéria graxa, proteína e fibra e o valor 100 .

4.2.3. Avaliação biológica da qualidade de proteína

4.2.3.1. Coeficiente de utilização protéica (CUP)

Foi determinado com base na metodologia da AOAC (1965): utilizou-se ratos da raça whister, machos, recém desmamados, mantidos em gaiolas individuais e em número de 6 por tratamento; a variação entre as médias de peso dos ratos 
foi de, no máximo, $5 \mathrm{~g}$ : Com base na composição do . material objeto de estudo, obtido conforme 4.2.2.1., as rações foram pre paradas de modo a se obter 10\% de proteínas, 8\% de óleo (as deficiências foram completas com óleo de algodão), 5\% de cin zas (as deficiências foram completas com misturas salina), 1\% de mistura vitamínica, 5\% de umidade, 1\% de fibra e 70\% de carboidratos (as deficiências foram completas com amido de mi lho). O grupo testemunha recebeu, na mesma proporção protéi ca, caseína como fonte de proteína.

No sentido de obter uma homogeneidade no prepa ro das rações, procedeu-se do seguinte modo: adicionou-se o óleo a uma parte do amido e misturou-se manualmente a fim de desmanchar os grumos e obter perfeita distribuição do óleo; a seguir, misturando, foram adicionados progressivamente a mis tura salina, a mistura vitamínica, o produto a. ser analisado e, finalmente, o resto do amido. A ração assim pronta foi manti da a $20^{\circ} \mathrm{C}$.

o período de ensaio foi de 4 semanas. Regis trou-se o peso de cada rato no início do ensaio e o peso do rato e quantidade de ração consumida a cada 7 dias e no últi mo dia de ensaio. Ração e água foram ministradas à vontade.

\subsubsection{Análise sensorial}

O preparo do material obedeceu à técnica de IIJAS et alii (1970): após a fermentação, os produtos foram cortados em cubos com $2,5 \mathrm{~cm}$ de lado e submetidos a ação do calor $\left(120^{\circ} \mathrm{C} / 10 \mathrm{~min}\right)$ para inativação enzimática; posteriormen te, foram secos em estufa com circulação forçada de ar $\left(60-65^{\circ} \mathrm{C} / 8\right.$ - $\left.10 \mathrm{~h}\right)$. Devido a secagem, a dimensão lateral dos cubos reduziu-se para $2 \mathrm{~cm}$, medida essa requerida para a análise sensorial. O material seco foi guardado em sacos plásticos, mantidos à temperatura ambiente. Para a fritura, o material foi imerso em uma solução salina a 5\% por um perío do de tempo de $30 \mathrm{~min}$ (TFS) e $5 \mathrm{~min}$ (tempeh). 
A fritura foi realizada em óleo de arroz, à temperatura de $100^{\circ} \mathrm{C}$ por $1 \mathrm{~min}$, em recipientes separados, um para cada tratamento.

Para a análise sensorial, utilizou-se o método de escala hedônica de 9 pontos para medir a preferência de sabor, segundo técnica de JORGE e GARRUTTI (1964). Para isso, após a fritura, os tratamentos foram colocados em pires nume rados (numeração casualizada) de fundo escuro, na quantidade de um pedaço de cada tratamento por pires e servidos (os 4 tratamentos) a 10 provadores, localizados em cabines isoladas a fim de evitar troca de informações. Após a degustação do material, cada provador preencheu o questionário de avaliação (Fig. 3) previamente incluido nas cabines, junto com as amos tras.

\subsubsection{Anālise estatística}

Para a análise sensorial, utilizou-se delinea mentos de blocos ao acaso, com 6 repetições e para as demais análises foi empregado delineamento inteiramente casuajizado, com 5 repetições, conforme PIMENTEL GOMES (1966)。 Os resultados, obtidos em porcentagem, foram convertidos em $\operatorname{arc} \operatorname{sen} \sqrt{\mathrm{P} / 100}$ (em que $\mathrm{P}$ é a porcentagem) para fins de dis tribuição binomial.

Utilizou-se um nível de significância de 5\%, sen do que as médias dos tratamentos foram analisadas pelo teste de Tukey. 
25.

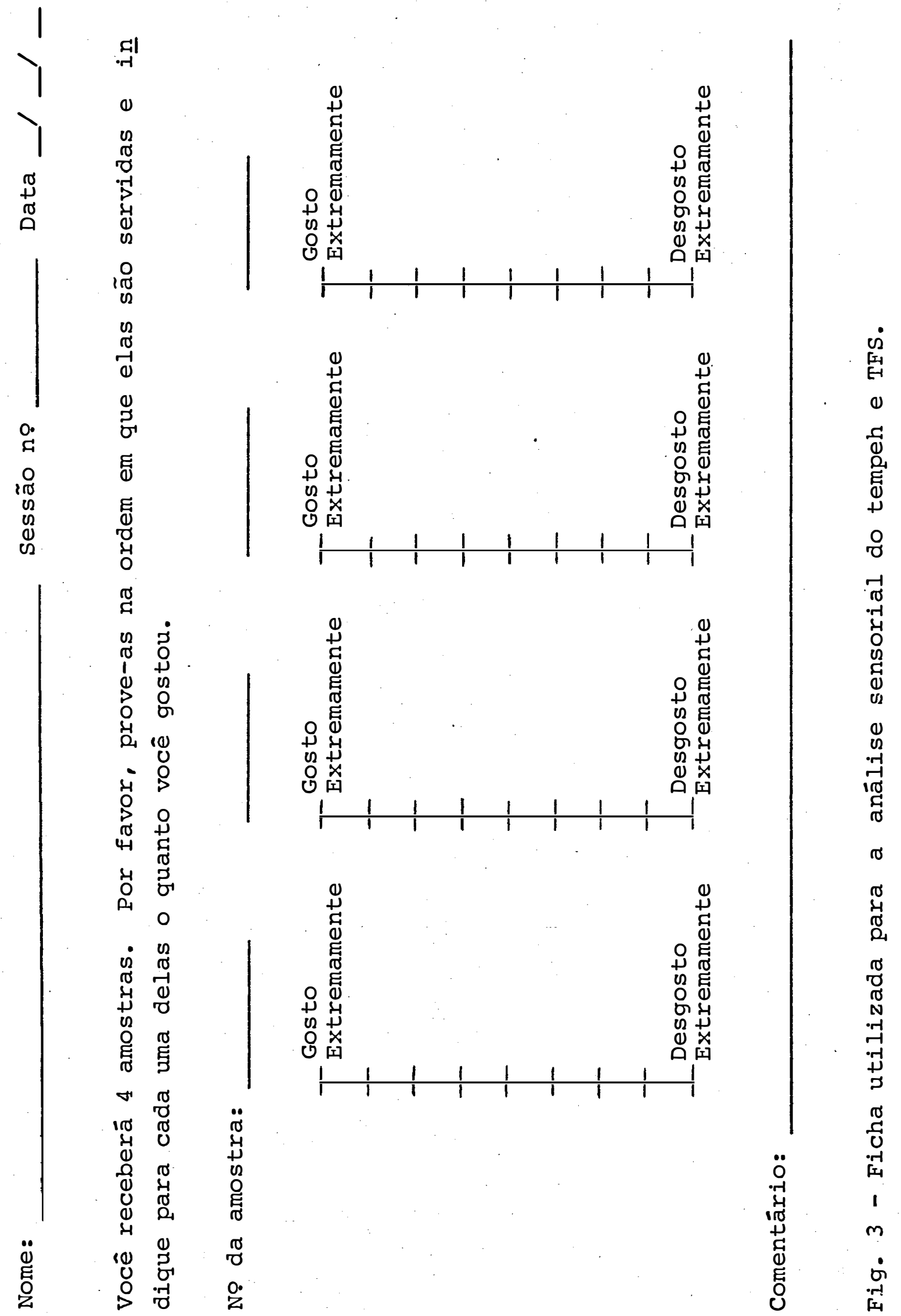


5. RESULTADOS E DISCUSSÃO

\subsection{Tempeh de farelo de soja.}

Após fermentação, O TFS apresentou-se com co loração branca (Fig. 4), devido ao micélio do fungo que cres ceu externamente ao mesmo. Porém, a colocação da mistura na placa de Petri, de modo frouxo, proporcionou uma aeração sufí ciente para o desenvolvimento do fungo no interior da mesma, unindo os grânulos do farelo suplementado, de modo a se obter um aspecto de bolo compacto. Esses aspectos são semelhantes aos obtidos com o tempeh, com a diferença que este mostra os grãos de soja distribuídos na massa branca e aquele dos grânu los de farelo com a coloração típica castanha. Também, a tex tura do TFS é macia, enquanto que no tempeh é mais dura, devi do aos grãos de soja. O odor do tempeh é descrito por STEINKRAUS et alii (1960) como "limpo e agradável e um aroma semelhan te a queijo". No caso do TFS observou-se odor de frutas, algo alcoólico, a semelhança do que foi obtido por van vEEN et alii (1958) e NAHAS et alii (1978 a) com o "ontjom" (produ to fermentado de torta de amendoim), ou ainda uma fragância de frutas, ésteres e ácidos doces mencionada por QUINN e BEUCHAT (1975), na fermentação de farinha de amendoim desengordurada pelo fungo Neurospora sitophiza. E possível que esse aroma 
seja devido, como mencionam QUINN et alii (1975), a compostos voláteis de baixo peso molecular, como ácidos, dióxido de car bono, ésteres, aldeidos, cetonas e outros produtos.

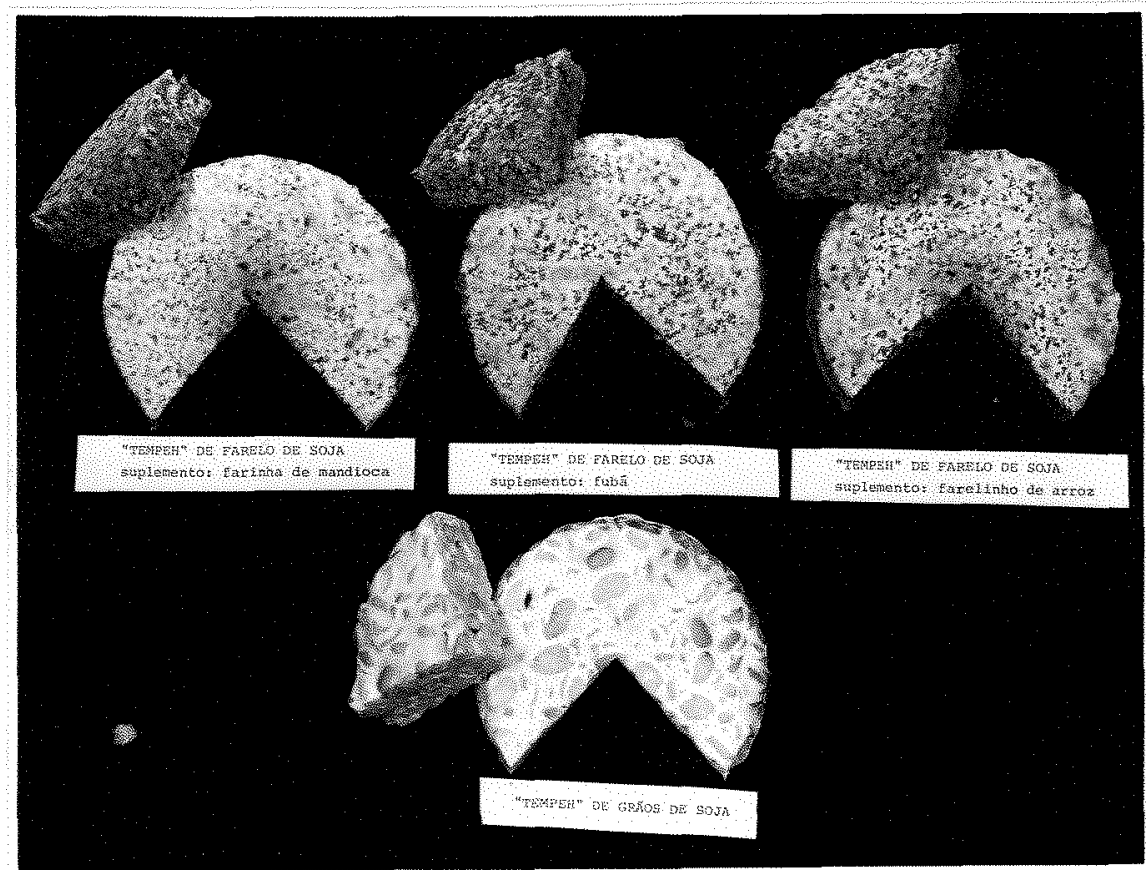

Fig. 4 - O TFS apresenta-se com coloração branca devido ao mi célio que recobre a sua superfície, a semelhança do tempeh.

Algumas variáveis foram consideradas para se obter uma boa fermentação do farelo de soja:

$\mathrm{pH}$ - a acidificação do farelo de soja foi ne cessária para inibir o crescimento de microrganismos indesejā veis que produziriam odores e aspecto desagradáveis ao produ to fermentado. A redução do $\mathrm{pH}$ para aproximadamente 4,5 foi suficiente para se conseguir o efeito desejado, sem inibir o desenvolvimento do fungo, uma vez que está dentro da faixa ótima ( $\mathrm{pH} 2,6$ a 5,3 ) do $R$. oligosporus (SORENSON e HESSELTINE, 
1966). O pH 4,5 foi obtido com a adição de 3,5\% de ácido cí trico do peso da mistura de farelo de soja suplementado.

A acidificação para um nível de $\mathrm{pH}$ de $4,5-5,0$ em torta ou farelo de amendoim foi também empregada por van VEEN et alii (1958) e QUINN e BEUCHAT (1975), por meio de ácí do cítrico, e por NAHAS et alii (1978 a), por meio de ácido tartárico, a fim de favorecer o desenvolvimento de Neurospora sitophiza.

A esterilização do farelo, como medida para se evitar subfermentação, prejudica o material, tornando-o com aspecto enegrecido ou de queimado.

Suplementação - a necessidade de se adicionar um suplemento para se produzir TFS pode ser deduzida pelos va lores de $\mathrm{pH}$ e temperatura apresentados na tabela 1 , os quais poderão ser melhor visualizados através dos gráficos das figu ras 5 e 6 . A fim de se comparar o desenvolvimento do fungo no farelo suplementado ou não, houve necessidade (apenas para esse ensaio) de se inocular o tratamento farelo, conforme téc nica descrita em 4.2.1.1.

Observa-se na tabela 1 que para o farelo trata do (inoculado), houve uma elevação do $\mathrm{pH}$ de 4,6 para 6,3, após 20 horas de fermentação. e para 7,7, após 30 horas, esta bilizando-se a seguir. Nos demais tratamentos suplementados, a maior elevação de pH coincidiu com a fase de maior desenvol vimento, porém, essa ascensão não foi tão brusca como observa do no farelo tratado (inoculado): com 20 horas de fermentação, anotou-se os valores de 4,6 (T. mandioca), 5,0 (T. fubá) e 5,4 (T. arroz). O ph continuou em ascensão nesses tratamen tos, porém, sempre foi inferior ao farelo tratado.

A temperatura inicial anotada na mistura em fermentação foi a do ambiente $\left(27^{\circ} \mathrm{C}\right)$. Com 10 horas de fermen tação, não se percebeu ainda desenvolvimento fúngico e a tem peratura verificada $\left(35^{\circ} \mathrm{C}\right)$ foi devida à equiparação da tempera tura da mistura com a da estufa de incubação. Com 20 horas, 


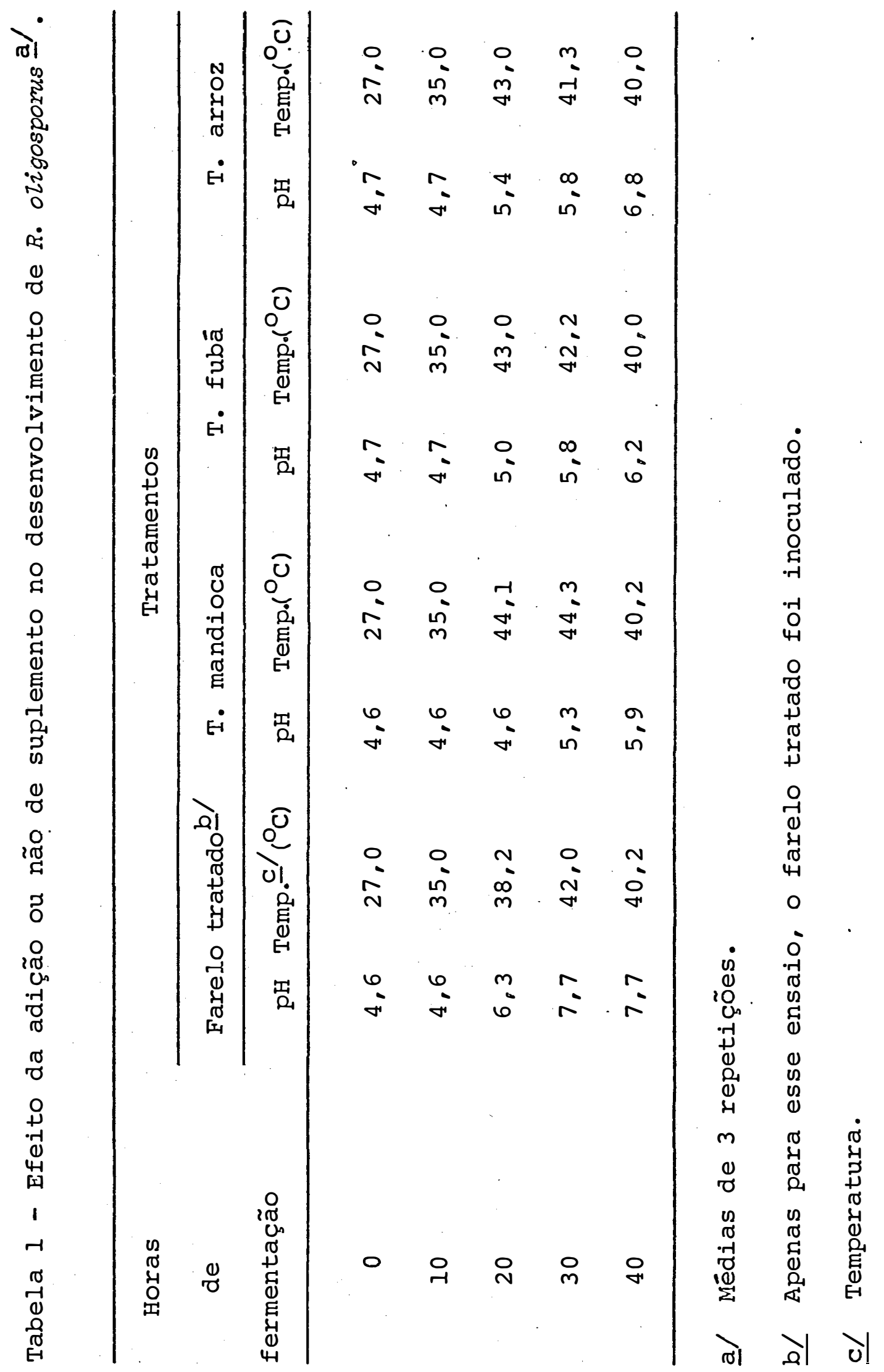


30 .

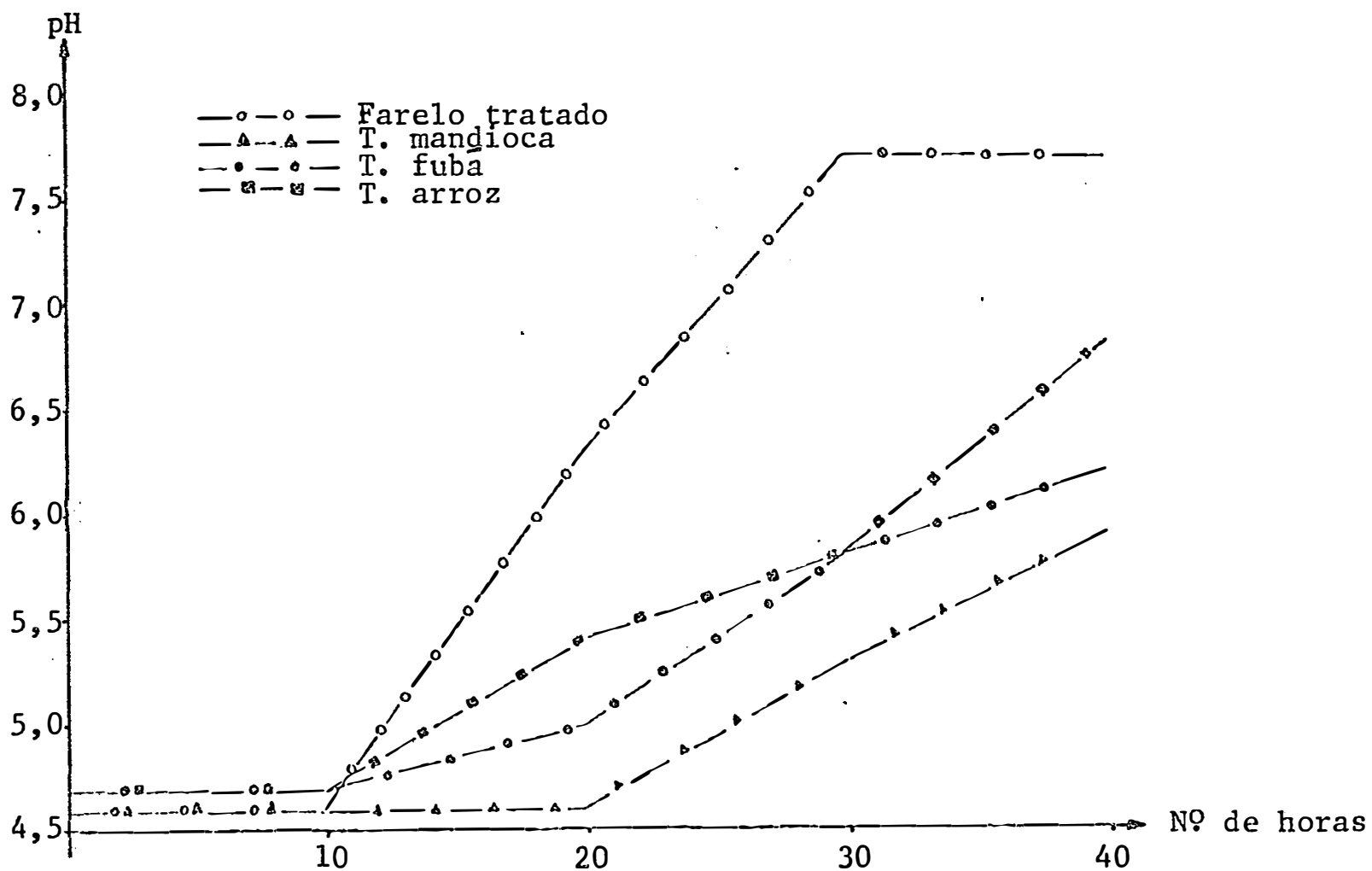

Fig. 5 - Variação do pH durante o desenvolvimento de $R$. oli gosporus em farelo de soja suplementado ou não. 
31.

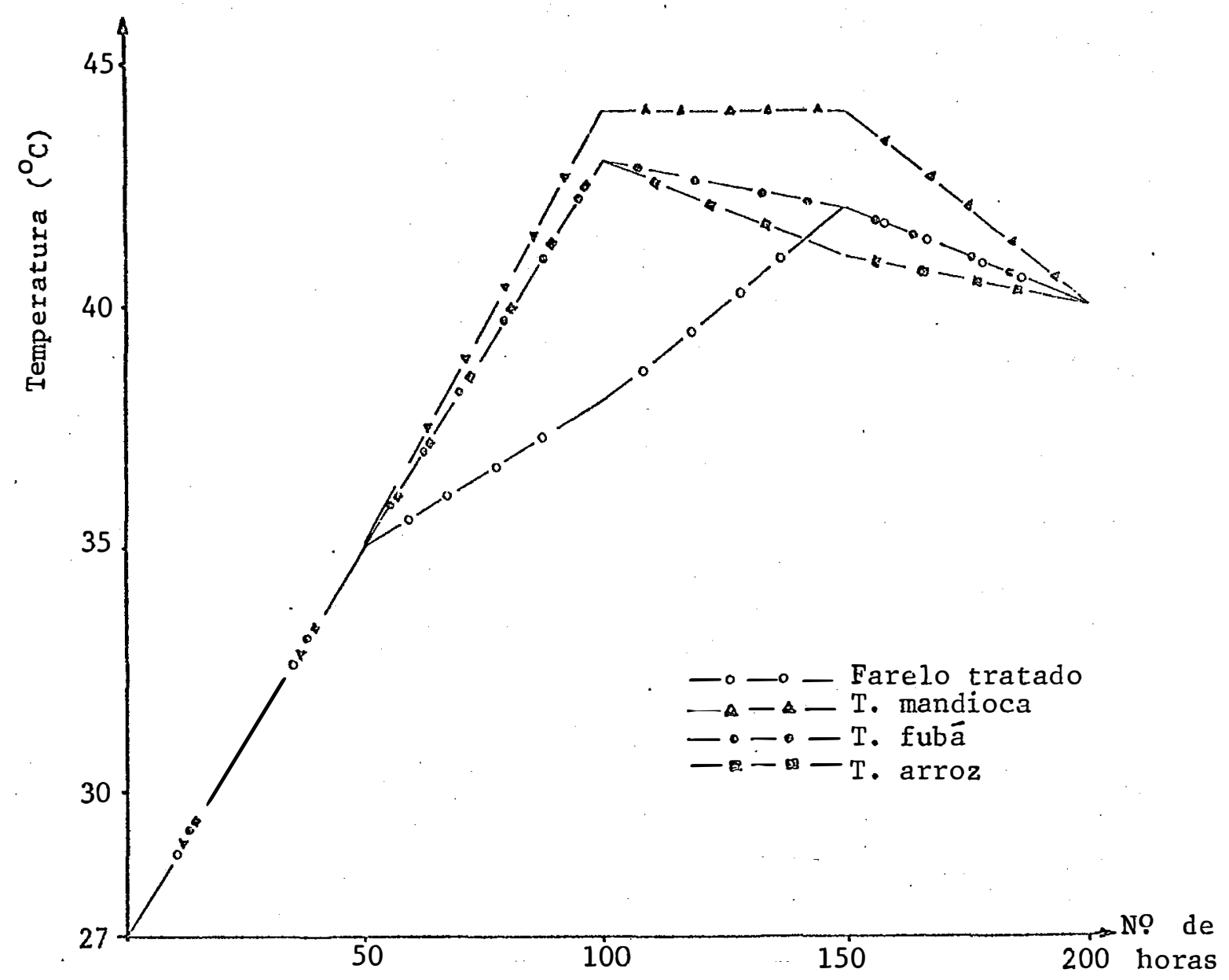

Fig. 6 - Variação da temperatura durante o desenvolvimento de $R$. oligosporus em farelo de soja suplementado ou não. 
foram atingidas as temperaturas máximas nos tratamentos suple mentados, em torno de $43-44^{\circ} \mathrm{C}$, quando se observou um cresci mento intenso do fungo, que se distribuía por toda a placa.

Ao mesmo tempo, no farelo tratado a temperatura anotada foi de $38,2^{\circ} \mathrm{C}$, com um crescimento incipiente do fungo. A partir de 30 horas de fermentação, a temperatura das placas com fare lo suplementado sofreu decréscimo gradativo indicando um re trocesso da atividade do fungo e, nesse tempo (30 horas), no farelo tratado anotou-se a temperatura máxima de $42^{\circ} \mathrm{C}$, porém, observando-se ainda pouco progresso no desenvolvimento do fun go e forte odor de amônea.

A elevação mais rápida da temperatura no TFS que no farelo tratado constitui o resultado de uma maior at vidade metabólica e, por conseguinte, maior desenvolvimento do fungo.

A temperatura atingida no TFS, de $44^{\circ} \mathrm{C}$, não inibe o fungo o qual ainda se desenvolve satisfatoriamente até $45^{\circ} \mathrm{C}$, como relatam STEINKRAUS et alii (1960).

O melhor desenvolvimento de $R$. oligosporus no farelo suplementado sugere uma melhor proporção na relação $\mathrm{C} / \mathrm{N}$ apresentada por esse material. Como esse fungo não utiliza carboidratos da soja (SORENSON e HESSELTINE, 1966), no farelo (não suplementado) o mesmo utilizaria proteínas como fonte de energia, as quais seriam desdobradas, acarretando elevada pro dução de amônea e consequente elevação do pH. WANG et alii (1968), a esse respeito, relatam maior consumo de carboidra tos do trigo em tempeh feito da mistura desse cereal com soja.

De qualquer forma uma elevação do $\mathrm{pH}$ sempre é esperada devido à atividade proteolítica do $R$. oligosporus (van VEEN e SHAEFER, 1950; HESSELTINE, 1965; e WANG e HESSELTINE, 1965).

Os dados de variação da temperatura verifica dos no TFS corroboram os encontrados por STEINKRAUS et alii (1960) e CAMARGO (1969) na fermentação de grãos de soja, os 
quais encontraram temperaturas máximas com $18-20$ horas e de pois diminuição das mesmas.

Com base no desenvolvimento do fungo e nos re sultados verificados na tabela 1 , adotou-se o período de fer mentação de 24 horas. O uso de suplemento na base de $30 \%$ do peso do farelo correspondeu à quantidade mínima necessária pa ra se obter uma boa fermentação do material de estudo.

Umidade - tendo em vista as necessidades de umidade pelo fungo serem relativamente altas (STEINKRAUS et alii, 1960) e com base nos ensaios tecnológicos, optou-se pe la adição de $150 \%$ de água destilada do peso da mistura de fá relo suplementado ou não porque: a) uma quantidade maior tor na a mistura mais compacta, acarretando problemas de aeração e, portanto, de desenvolvimento interno do fungo, embora favo reça o crescimento na superfície do substrato; b) correspon de a um teor de umidade de $60 \%$ do peso total, teor esse próxí mo ao obtido na fermentação da soja em grão, em torno de 62 67\%, segundo CAMARGO (1969).

\subsection{Rendimento, pH e umidade.}

Os dados resumidos resultantes das análises de $\mathrm{pH}$ e de umidade, os rendimentos calculados referentes ao fare lo, farelo tratado, tempeh e TFS estão apresentados na tabela 2 .

Pelos dados da tabela 2, observa-se que o fare lo suplementado apresentou um rendimento superior ao tempeh, da ordem de 65 a $70 \%$, o que era esperado uma vez que no prepa ro desse produto ocorrem perdas por descascamento, maceração, cozimento e fermentação, que podem chegar a 43\% (SMITH et alii, 1964) conforme o processo de preparo utilizado, perdas essas que não ocorrem, exceto a última, no farelo. 


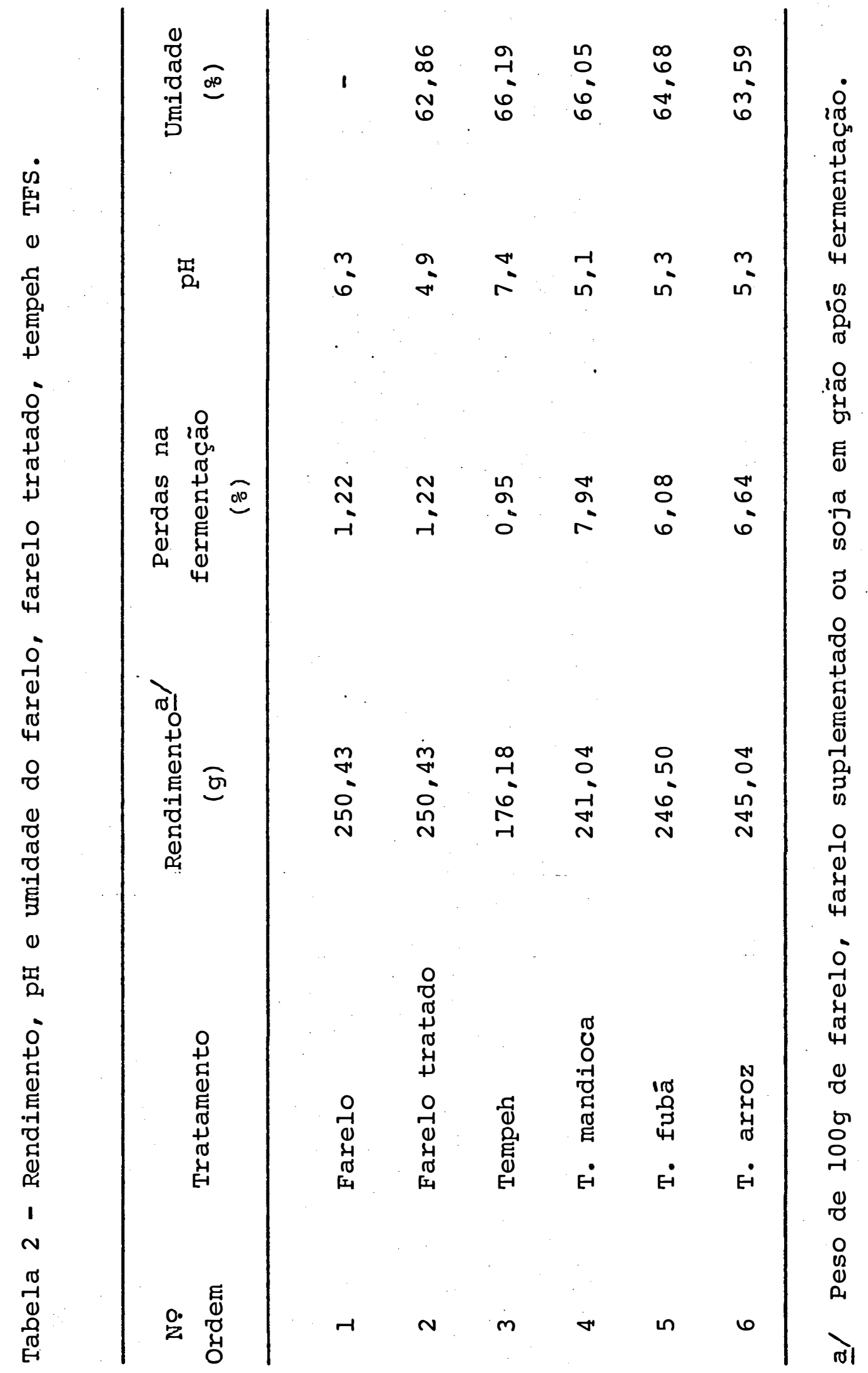


Dados de rendimento aqui obtidos podem ser re lacionados com os da literatura: assim, STEINKRAUS et alii (1960) obtiveram de $100 \mathrm{~g}$ de soja um rendimento de $174 \mathrm{~g}$, de tempeh e CAMARGO (1969), de 166 a $185 \mathrm{~g}$, portanto semelhantes aos obtidos neste trabalho. Por outro lado, verifica-se um rendimento elevado para os farelos fermentados; assim, NAHAS et alii (1978 b) obtiveram um rendimento de 273 a $294 \mathrm{~g}$ a par tir da fermentação do farelo de amendoim.

As perdas durante a fermentação foram 6 a 8 ve zes superiores nos farelos suplementados que no farelo trata do ou tempeh. Comparando-se os dados dos TFS com o respecti vo controle (farelo tratado), è de se supor que, além das pex das de umidade, haja evaporação de constituintes voláteis, que seriam formados em maior quantidade nos farelos suplementados, devido a maior superfície de exposição apresentada pelos grâ nulos do farelo à ação das enzimas do fungo.

A maior perda no T. mandioca (Tukey, 5\%) resul tou em menor rendimento nesse tratamento quando comparado com T. fubá ou T. arroz (tabela 2).

SMITH et alii (1964), confirmando os dados aqui obtidos, relatam perdas nos grãos de soja fermentados que va riam de 0,8 a $3,4 \%$, as quais se elevaram para 2 - 5\% em "chips" (grão de soja subdividido em $6-8$ partes). Por sua vez, STEINKRAUS (1964) relata perdas na fermentação de 1,7\% no tempeh.

$\mathrm{O} \mathrm{pH}$ do farelo de soja, de 6,3 (tabela 2) foi abaixado pelas razões anteriormente discutidas, para 4,5 4,6. A incubação em estufa do farelo tratado ou a fermenta ção dos farelos suplementados elevaram $0 \mathrm{pH}$ para níveis de 4,9 e $5,1-5,3$, respectivamente, enquanto que no tempeh re gistrou-se o pH de 7,4. A elevação do pH no farelo tratado deve-se a transformações decorrentes de contaminantes. A maior elevação do $\mathrm{pH}$ no tempeh que no TFS, deve-se ao $\mathrm{pH}$ inicial dos grãos de soja ser mais elevado (em torno de 6,8 ). 
Essa variação no pH foi também obtiḍa por STEINKRAUS et alii (1965), ao proceder a fermentação da soja pelo uso de Neurospora sp e de $R$. oligosporus quando $0 \mathrm{pH}$ se elevou de 4,6 - 4,7 até acima de 7,0, e por WANG e HESSELtinE (1965), para a produção de tempeh de trigo, quando o pH caiu de 6,8 para 5,7 e, então, gradualmente subiu até 6,7 .

Exceto para o T. arroz que apresentou um teor de umidade de cerca de $64 \%$, os demais farelos suplementados e o tempeh não diferiram significativamente, apresentando apro ximadamente 65 - 66\% de umidade. Como mencionam STEINKRAUS et alii (1960) e CAMARCO (1969), esse elevado teor de umidade torna o tempeh bastante perecível, devendo o mesmo ser pronta mente conservado após fermentação, fato esse também observado no TFS, apesar de apresentar pH ligeiramente inferior.

\subsection{Composição centesimal}

Os valores médios da composição centesimal do farelo, farelo tratado, tempeh e TFS estão na tabela 3, que inclui também os teores de proteína verdadeira e dispersa.

A análise estatística (teste F) mostrou que houve diferença significativa entre pelo menos duas médias em todos os itens analisados da composição centesimal, exceto pa ra proteína total.

Um exame dos dados da tabela 3 mostra que, de modo geral, o tempeh apresenta maior teor de matéria graxa, enquanto que os farelos suplementados possuem valores superio res dos demais itens da composição centesimal, quais sejam, cinza, fibra crua e carboidrato.

O exame dos dados apresentados pela literatura consultada revela uma similitude com os encontrados neste tra balho. Assim, os resultados da análise do farelo estão enqua drados dentro dos limites apresentados por PION (s/d) e bas tante próximos aos dados relatados por ORR e ADAIR (1967) e COSTA et alii (1976). 


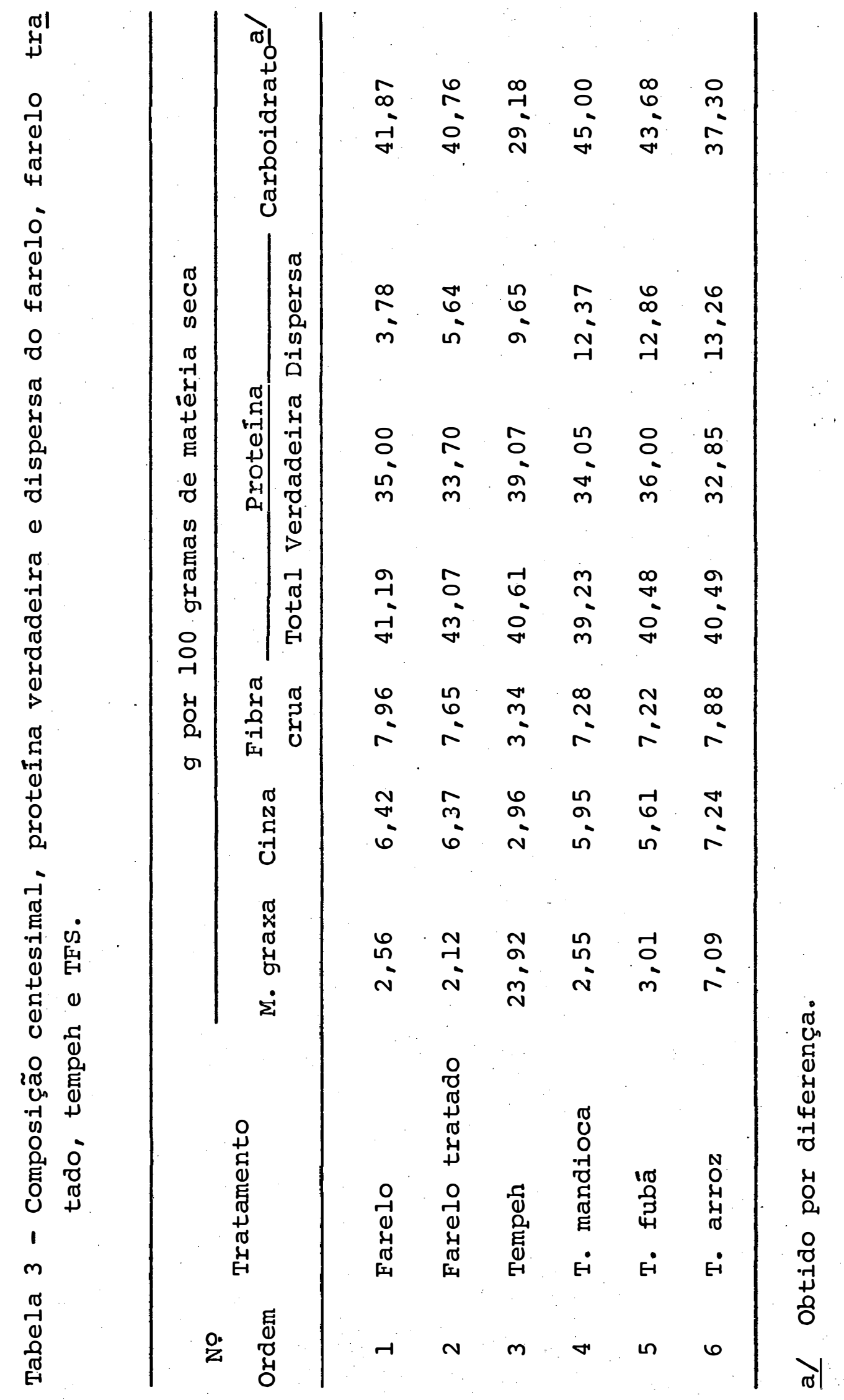


Não se notou diferença significativa: nas ca racterísticas analisadas (Tukey, 5\%) entre o farelo e o fare lo tratado, exceto para matéria graxa, mostrando que não hou ve influência da temperatura de incubação do material. A di minuição no teor de matéria graxa pode ser o resultado da sub fermentação ocorrida, como mencionado anteriormente, com utí lização desse componente pelos microrganismos presentes ou li beração de substâncias que são arrastadas pelo extrato etéreo.

De modo geral, como era esperado, os demais tratamentos diferenciaram-se entre si e com os controles. A adição dos diversos suplementos ao farelo conferiu uma compo sição diferente ao produto fermentado, como verificado nas aná lises realizadas. Conforme constatação bibliográfica (BRASIL. Ministério do Interior (a), s/d; MORRISON, 1966 e TOSELLO, 1975), os suplementos utilizados possuem alto teor de carboi dratos (acima de 70\% para o fubá e farinha de mandioca e 41\% para o farelinho de arroz), os quais foram utilizados para o desenvolvimento do fungo, conforme discutido anteriormente. O maior teor de cinza para O T. arroz decorre do maior conteú do desse componente no farelinho de arroz. STEINKRAUS et alii (1960), MURATA et alii (1967) e WANG et alii (1968) relatam uma aumento no teor de fibras, devido ao micélio fúngico. Nos nossos ensaios, verificou-se uma redução no teor de fibra crua em T. mandioca e T. fubá, em relação ao farelo, enquanto que no T. arroz foi estatísticamente igual ao farelo. Explica-se porque farinha de mandioca e fubá possuem baixo teor de fi. bras, enquanto que o farelinho de arroz apresenta alto conteú do desse componente, conduzindo dessa forma aos teores apre sentados.

Com relação à composição do tempeh analisado, verificou-se que se aproxima da apresentada por STEINKRAUS et alii (1960 e 1965), MURATA et alii (1967), LEITÃO et alii (1967/68), CAMARGO (1969) e van BUREN et alii (1972), excetú ando o teor de proteína, que se mostrou ligeiramente inferior, 
porém, mais próximo ao apresentado pelo último autor (em tor no de $41,5 \%)$.

o teor inferior de óleo nos farelos suplementa dos constitui uma desvantagem em relação ao tempeh, por quan to o óleo de soja é considerado altamente desejável na dieta (ELDER e RATHMANN, 1962).

Apesar dos teores de proteína total dos suple mentos serem inferiores ao do farelo, não se constatou dife rença significativa dessa característica entre TFS, farelo e tempeh, apresentando valores que variaram de 39 a $43 \%$.

Com relação à proteína verdadeira, não se ob servou diferença significativa entre os controles farelo e farelo tratado, cujo teor veriou de 34 - 35\%. A adição de fú bá elevou o teor de proteína verdadeira do fárelo para 36\%, porém não de forma significativa. O T. mandioca apresentou um valor estatísticamente igual e o T. arroz inferior ao fare 10, respectivamente. Por outro lado, o tempeh superou os de mais tratamentos com um teor de proteína verdadeira de $39 \%$

Os dados de proteína dispersa mostraram que por ação de $R$. oligosporus houve aumento significativo desse valor quando comparado com os do TFS e do farelo. Assim, o teor de proteína dispersa foi de $3,3-3,5$ vezes maior no TFS que no farelo. Verificou-se, ainda, um teor 1,3-1,4 vezes maior no TFS que no tempeh, devido a maior ação enzimática co mo discutido anteriormente. Esses resultados vêm confirmar os relatos de van VEEN e SHAEFER (1950), HESSELTINE (1965), WANG e HESSELTINE (1965) e CAMARGO (1969) sobre a atividade proteolítica do $R$. oligosporus. Dados numéricos coletados na literatura mostram um aumento no teor de $\mathrm{N}$ solüvel (não foram encontrados dados de proteína dispersa) durante a fermentação do tempeh, de 0,5 para $2-2,5 \%$ (STEINKRAUS. et alii, 1960 e HESSELTINE, 1965) enquanto que van BUREN et alii (1972) veri ficaram um aumento no teor de proteína crua solúvel, em 24 ho ras de fermentação, de 1,85 para 13,9\%, portanto, confirmando os resultados aqui obtidos. 


\subsection{Valor nutritivo}

As médias de ganho de peso e de consumo de ra ção pelos ratos de ensaio e os respectivos C.U.P. do farelo, farelo tratado, tempeh, TFS e a caseína tomada como padrão es tão na tabela 4 .

Tabela 4 - Ganho de peso, consumo de ração e C.U.P. de farelo, farelo tratado, tempeh, TFS e caseína padrão.

\begin{tabular}{clccc}
\hline $\begin{array}{l}\text { No } \\
\text { Ordem }\end{array}$ & Tratamento & $\begin{array}{c}\text { Ganho de peso } \\
(\mathrm{g})\end{array}$ & $\begin{array}{c}\text { Consumo de ração } \\
(\mathrm{g})\end{array}$ & C.U.P. \\
\hline 1 & Farelo & 37,8 & 214,9 & 1,88 \\
2 & Farelo tratado & 35,8 & 203,0 & 1,77 \\
3 & Tempeh & 37,8 & 252,5 & 1,78 \\
4 & T. mandioca & 48,0 & 242,9 & 1,87 \\
5 & T. fubá & 52,7 & 234,9 & 2,39 \\
6 & T. arroz & 33,8 & 210,4 & 1,80 \\
7 & Caseína & 63,9 & 234,1 & 2,50 \\
\hline
\end{tabular}

Analisando-se os dados da tabela 4, pode-se ve rificar que o consumo de ração de T. mandioca, T. fubá e cá seína foi mais ou menos próximo (234 - $243 \mathrm{~g})$, enquanto que o tempeh foi o mais consumido $(253 \mathrm{~g})$ e o farelo, farelo tra tado junto com o T. arroz foram os menos consumidos $(203$ $215 \mathrm{~g})$ pelos ratos de ensaio. 
Embora o tempeh fosse o mais consumido, apre sentou um ganho de peso (de $38 \mathrm{~g}$ ) relativamente baixo. Como se observa na Fig. 7, onde foi traçado o ganho semanal de pe. so dos ratos de ensaio, T. fubá e caseína mostram uma caracte rística ascendente, enquanto que nos demais tratamentos ocor reu uma queda no crescimento a partir da 2 a semana de ensaio. Entretanto, no T. mandioca, os ratos apresentaram um ganho de peso superior aos demais tratamentos (exceto caseína) já a partir da $2^{\underline{a}}$ semana, ganho esse que declinou no final do en saio ( 4 a semana).

E de se notar que apenas T. mandioca $(48 \mathrm{~g})$ e T. fubá (aproximadamente $53 \mathrm{~g}$ ) proporcionaram um ganho de pe so superior ao farelo $(38 \mathrm{~g})$. Esse tipo de resultado foi tam bém observado por WANG et alii (1968) com trigo fermentado com R. oligosporus, van VEEN et alii (1968) com torta de amendoim fermentada e CAMARGO (1969) com tempeh de soja das variedades Hardee e L-1556.

Apesar dos resultados conseguidos com T. man dioca e T. fubá, não se obteve diferença significativa en tre o C.U.P. desses tratamentos com o do farelo, os quais apresentaram, respectivamente, os valores de 1,87, 2,39 e 1,88. Também, não foi encontrada diferença estatística (Tû key, 5\%) entre esses valores e o padrão caseína (C.U.P. $=2,50$ ). o farelo garantiu um valor C.U.P. de 1,88 devido ao maior ga nho de peso dos ratos em relação ao consumo de ração, quando comparado com outros tratamentos. Por outro lado, farelo tra tado $(1,77)$, tempeh $(1,78)$ e T. arroz $(1,80)$ foram significa tivamente inferiores ao farelo.

Esses resultados levam a concluir que embora a fermentação não tivesse melhorado a qualidade do farelo su plementado (havendo, ainda, redução do seu valor), por outro lado ocorreu um substancial ganho de peso dos ratos no T. man dioca e T. fubá e que pelo menos esse último tratamento apre sentou um C.U.P. tão alto $(2,39)$ quanto ao da caseína $(2,50)$, indicando uma distribuição mais equilibrada dos aminoácidos do 


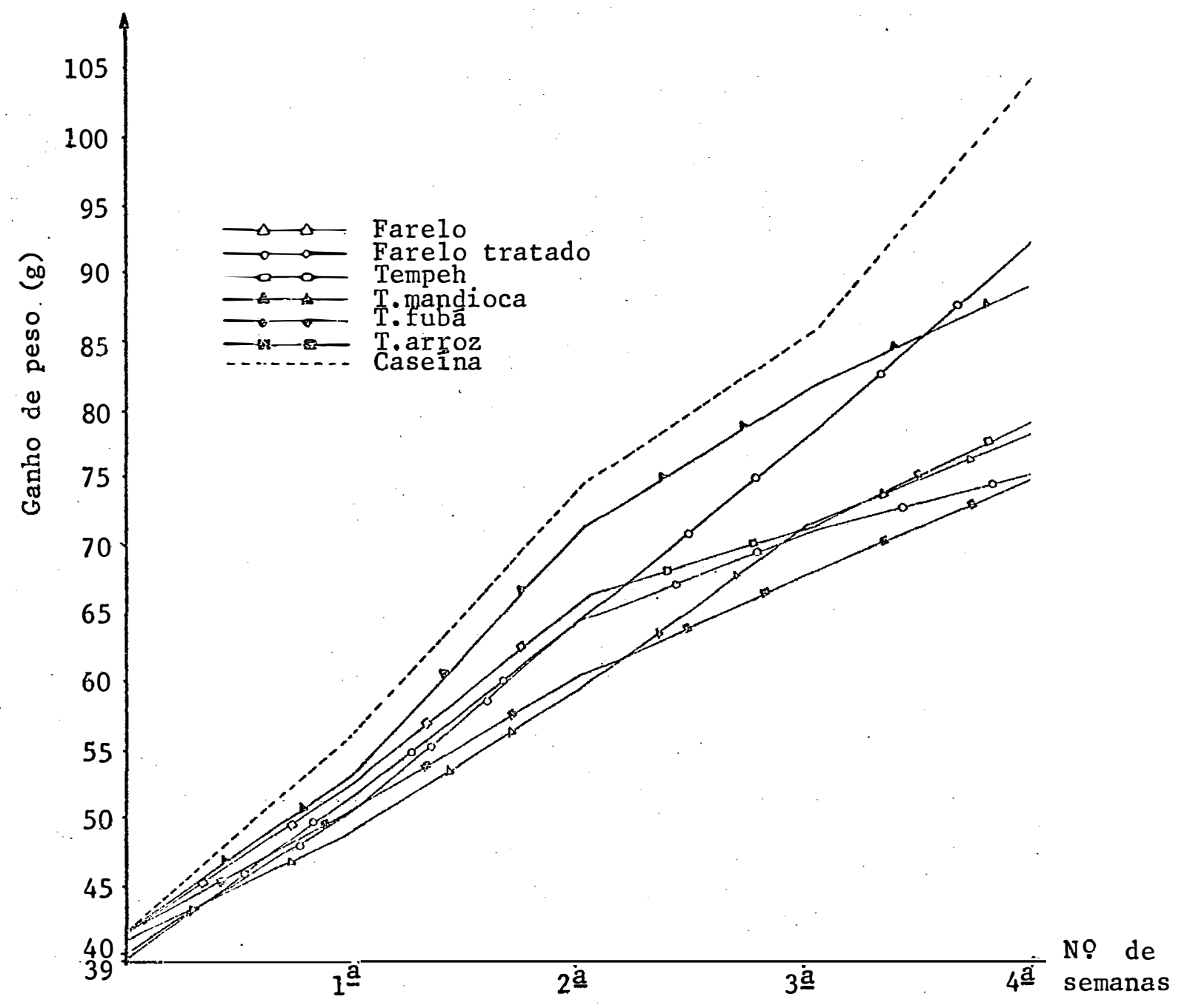

Fig. 7 - Ganho semanal de peso verificado nos ratos de ensaio ao consumirem farelo, farelo tratado, tempeh, TFS e caseîna. 
farelo quando suplementado com fubá e uma melhoria da qualí dade do farelo (não apontada estatisticamente).

Corroborando os dados aqui encontrados, verifi ca-se que, de modo geral, a fermentação da soja não melhora o valor biológico do alimento. Assim, os dados de C.U.P. apre sentados por HACKLER et alii (1964), SMITH et alii (1964), WANG et alii (1968), CAMARGO (1969) e MURATA et alii (1970) mostraram que não ocorre melhoria desse indice o qual pode, ainda, ser reduzido. Por outro lado, WANG et alii (1968) men ciona que o C.U.P. do trigo foi aumentado por fermentação.

\subsection{Análise sensorial}

Na tabela 5 estão relacionadas as médias das notas atribuídas pelos provadores ao tempeh, T. mandioca, T. fubá e T. arroz.

Tabela 5 - Médias das notas atrịbuídas pelos provadores ao tempeh, T. mandioca, T. fubá e T. arroz.

\begin{tabular}{clc}
\hline No Ordem & Tratamento & Médias \\
\hline 1 & Tempeh & 4,7 \\
2 & T. mandioca & 4,3 \\
3 & T. fubá & 4,4 \\
4 & T. arroz & 3,8 \\
\hline
\end{tabular}

A anālise estatística mostrou que não houve preferência na aceitação dos diferentes alimentos estudados; tempeh ou TFS, sendo que as médias das notas atribuídas pelos 
provadores variaram de 3,8 a 4,7. Os resultados obtidos mos traram também que a aceitação de qualquer produto analisado está abaixo da média da escala hedônica (valor 1 a 9) adotada. Os comentários anotados pelos provadores nas fichas de avalia ção foram poucos e não chegaram a ser conclusivos. Entretan to, a tabulação desses comentários revelou algumas caracterís ticas que foram mencionadas com maior freqüência, qual seja textura dura para o tempeh, textura mole ou muito mole para o T. arroz e sabor bom, regular ou harmonioso para T. mandioca e T. fubá.

CAMRGo (1969), num teste de preferência de tempeh feito com várias variedades de soja, conseguiu uma co tação mais alta que a obtida neste trabalho, cotação essa que variou entre 5 a 9, na escala de 10 pontos adotada. Esse au tor utilizou a técnica de fritura do material fresco, técnịca essa que foi experimentada nos trabalhos preliminares, mas 0 material assim frito mostrou-se encharcado de óleo e foi pre terido ao material frito, mas seco previamente. ILJAS et alii (1970) não encontraram diferença significàtiva na análise sen sorial do tempeh preparado dessas duas formas com a vantagem do produto seco ser conservado mais facilmente. Einteressan te ressaltar que apesar do tempeh ser um prodúto com restrí ções de uso no Brasil, apresenta determinadas características organoléticas conforme assinalam van VEEN e SHAEFER (1950) e HESSELTINE (1965) que o tornaram altamente aceito na Europa e nos Estados Unidos, respectivamente. 


\section{CONCLUSÕES}

1- No processo tecnológico de preparo do tempeh de farelo de soja (TFS) verificou-se a necessidade da adição de um suplemento de carboidrato, na quantidade mínima de $30 \%$ do peso de farelo, da acidificação a um pH 4,5, conseguida com a adição de $3,5 \%$ de ácido cítrico do peso de mistura (farelosuplemento) e de se manter um nivel de umidade para fermenta ção, em torno de $60 \%$.

$$
\text { 2- O TFS possui aspecto de um bolo de colora }
$$
ção branca onde os grânulos de farelo aparecem unidos pelo mi célio do fungo, a semelhança do tempeh. Difere deste, ná tex tura, que è mais macia, e no odor, que é de frutas, algo al coólico.

3- O rendimento do TFS é 24 - 26\% superior ao tempeh, o teor de umidade é bastante próximo $(63-66 \%)$ e o $\mathrm{pH}$ é levemente ácido $(5,1-5,3 \%)$ no TFS e praticamente neu tro no tempeh (tabela 2).

4- A análise da composição centesimal (tabe la 3) mostrou que o teor de proteína total foi estatisticamen te igual no farelo, tempeh e TFS. Por outro lado, os demais itens da composição centesimal, exceto matéria graxa, aparece 
ram em maior quantidade no farelo e TFS que no tempeh (tabe la 3).

5- o teor de proteína verdadeira foi superior no tempeh (39\%) que no TFS $(32-36 \%)$. Apenas o TFS suplemen tado como fubá mostrou-se superior ao farelo ( $36 \%$ x $35 \%$ ), po, rēm não significativamente.

6- A fermentação proporcionou um aumento de 3,3 - 3,5 vezes no teor de proteína dispersa e 1,3-1,4 vezes maior no TFS que no tempeh, indicando um aumento da digestibi lidade no produto fermentado.

7- Não se verificou melhoria do valor biológi co da proteína do farelo (C.U.P. $=1,88$ ) relativo aos tratamen tos suplementados de fubá $(2,39)$ e de mandioca $(1,87)$, os quais se mostraram estatísticamente iguais ao padrão de casei na. Embora esses valores sejam superiores ao do tempeh $(1,78)$ e do T. arroz $(1,80)$.

8- Pela análise sensorial, O TFS foi regular mente aceito pelos provadores (tabela 5), não havendo prefe rência quando cotejado com o tempeh. 


\section{SUMMARY}

The possibility of fermentation of soybean meal (by product of the oil industry) to produce a tempeh like product, an oriental food, originally made of coocked soybean grains, was tried. The technological process has shown the necessity of addition to the soybean meal, a mini mum of $30 \%$ of a supplement as source of carbohydrate, as manioc cassava flour, maize flour and rice bean, 3.5\% of cit ric acid to decrease the $\mathrm{pH}$ to 4.5 and also $150 \%$ of distilled water considering the weight of the mixture soybean mealsupplement. The mixture was fermented in Petri dishes, at $35-37^{\circ} \mathrm{C}$ during 24 hours using the mold Rhizopus oligosporus. After fermentation it has been obtained a product called soybean meal tempeh (TFS) which was like a compact white cake, with a pleasant fruit smell and showing also $\therefore$ a something alcoolic smell.

The TFS was analysed in relation to tempeh and soybean meal for its biochemical, biological and the most important sensorial characteristics. The results have shown that the TFS has a similar content of total protein, less oil content and more quantities of crude fiber, ashes and carbohy drates than the tempeh. The fermentation neither changes the percent composition, except for lipids content nor improved 
48.

the crude protein content when the TFS was compared with the soybean meal, but the content of the dispersible protein was increased $3.3-3.5$ times. This suggests an improvement of the digestibility of the TFS. The protein efficiency ratio of the TFS was similar to the soybean meal and that of stand ard casein and superior to the one of tempeh. The sensorial analysis has shown that TFS was regularly accept like tempeh. 
8. LITERATURA CITADA

AMERICAN ASSOCIATION OF CEREAL CHEMISTS. 1969. Aproved meth od of the AOCS. Minnesota, USA, AACC, $s / p$ (vol.1).

AMERICAN OIL CHEMISTS' SOCIETY. 1964. Official and tenta

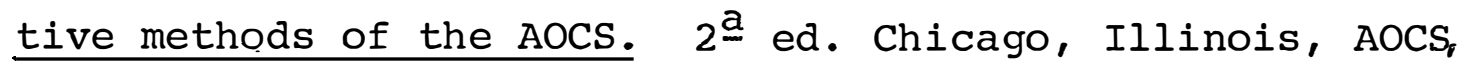
$\mathrm{s} / \mathrm{p}$.

ASSOCIATION OF OFFICIAL AGRICULTURAL CHEMISTS. 1965. Offi cial methods of analysis. William Horwitz. 10 a $\overline{\text { ed }}$. Washington, AOCS, $957 \mathrm{p}$.

BELTER, P.A. e A.K. SMITH. 1951. Protein Denaturation : in Soybean Meal During.. Processing o. J。Am. Oil Chem. Society $\underline{29}(5): 170-174$.

BRASIL. 1976. Fundação Instituto Brasileiro de Geografia e Estatística. Anuário Estatístico do Brasil. Rio de Ja neiro, IBGE, 816 p. (vol. 37).

BRASIL. Ministério do Interior (a). s/d. Contribuição ao desenvolvimento da agroindústria. Arroz. Campinas, Fun dação Centro Tropical de Pesquisa e Tecnologia de Alimen tos, 166 p. (Vol. VIII). 
BRASIL. Ministério do Interior (b). s/d. Contribuição ao de senvolvimento da agroindústria. Soja. Campinas, funda ção Centro Tropical de Pesquisas e Tecnologia de Alimen tos, 173 p. (vol. X).

CAMARGO, R. 1969. Contribuição ao estudo de dois alimentos. orientais - o tempeh e o tofu - obtidos da soja (Glycine max (L.) Merrill). Tese para Livre Docência. Piracicaba, ESALQ, $88 \mathrm{p}$.

COSTA, S.I.; D.G. QUAST; N.A. NORETTI; W.L. CANTO e R.V. COBBE. 1976. O emprego da soja na alimentação humana. Bol. Inst. Tec. Alimentos, $46: 1-24$.

DIOKNO-PALO, N. e M.A. PALO. 1968. Two Philippine species of Phycomycetes in tempeh production from soybean. Philip pine J. Sci., $97(1): 1-17$.

DJIEN, K.S. e C.W. HESSELTINE. 1961. Indonesian fermented foods. Soybean Digest, 22(1):14-15.

ELDER, A.L. e D.M. RATHMANN. 1962. Seed oils in human nutri tion. Economic Botany, 16(3):196-205.

EVANS, R.J. e S.L. BANDEMER. 1967. Nutritive values of some oilseed proteins. Cereal Chemistry, $44(5): 417-426$.

HACKLER, L.R.; K.H. STEINKRAUS; J.P. BUREN e D.B. HAND. 1964. Studies on the utilization of tempeh protein by weanling rats. J. Nutrition, $82: 452-456$.

HART, F.L. e H.J. FISHER. 1971. Modern food analysis. New York, Springer-Verlag, 519 p. 
HESSELTINE, C.W. 1965. A millenium of fungi, food, and fer mentation. Mycologia, $57(2): 149-197$.

HESSELTINE, C.W.; G. HAVEN e A. MARTINELLI JR. 1966. Methods for producing tempeh. Patente no 3.228.773. Estados Uni dos, $3 \mathrm{p}$.

HESSELTINE, C.W. e H.L. WANG. 1967. Traditional fermented foods Biotech. Bioeng. IX:275-288.

ILJAS, N.; A.C. PENG e W.A. GOULD. 1970. Tempeh. Find ways to preserve Indonesian soy food. Ohio Report, 55:22-23.

JORGE, J.P.N. e R.S. GARUTTI. 1964. Métodos estatísticos aplicadós à anālise sensorial de alimentos e bebidas. Bol. Inst. Agron. Campinas, no 137. 9 p.

LEITÃO, M.F.F.; T.J.B. MENEZES e J.S. TANGO. 1967/68. Produ ção de "tempeh", produto fermentado de soja. Col. do Ins tituto de Tecnologia de Alimentos (Campinas), 2:333-339.

MARTINELLI, A. e C.W. HESSELTINE. 1964. Tempeh fermentation: package and tray fermentations. Fd. Technol. 18(5): 167171.

MORRISON, F.B. 1966. Alimentos e alimentação dos animais. Trad. de J.S. Veiga. 2âa ed. São Paulo, Melhoramentos, 892 p.

MURATA, K.; H. IKEHATA e T. MIYAMOTO. 1967. Studies on the nutritional value of tempeh. J. of Food Sci. 32:580-586.

NAHAS, E.; R. CAMARGO e R.P. SCHOCKEN. 1978 a. Fermentação do farelo de amendoim. I. Ensaio tecnológico. Científica, 6(1). (no prelo). 
NAHAS, E.; R. CAMARGO e J.J. OLIVEIRA JR. 1978 b. Fermentą ção do farelo de amendoim. II. Composição centesimal e valor nutritivo. Cientifica. (no prelo).

ORR, E. e D. AIDAR. 1967. The production of protein foods and concentrates from oilseeds. Tropical Products Insti. tute. G 31. 104 p. + ap.

PIMENTEL GOMES, F. 1966. Curso de Estatistica Experimental. 3a ed. Piracicaba, ESALQ. 404 p.

PION, R. 1973. Composition des aliments vegetaux en protides et en acides amenēs. Revue Française de Dietetique, 66 : $3-15$.

PION, R. s/d. Composition et teneur en acides amines des tourteaux. INRA, p. 27-34.

QUINN, M.R. e L.R. BEUCHAT. 1975. Functional property changes resulting from fungal fermentation of peanut flour. J. Food Sci., 40:475-478.

QUINN, M.R.; L.R. BEUCHAT; J. MILLER; C.T. YOUNG e R.E. WOR THINGTON. 1975. Fungal fermentation of peanut flour: effects on chemical composition and nutritive value. J. Food Sci. $40: 470-474$.

ROELOFSEN, P.A. e A. TALENS. 1964. Changes in some vitamins during molding of soybeans by Rhizopus oryzae in the pro duction of tempeh kedelee. J. Food Sci. 29 (2):224-226.

ROHR, R. 1973. Óleos e gorduras vegetais. Seus protudos protéicos. UNICAMP. $184 \mathrm{p}$. 
SARRUGE, J.R. e H.P. HAAG. s/d. Análises químicas em plan tas. Piracicaba, ESALQ, $56 \mathrm{p}$.

SMITH, A.K.; J.J. RACKIS; C.W. HESSSELTINE, M. SMITH; D. J. ROBBINS e A.N. BOOTH. 1964. Tempeh: nutritive value in relation to processing. Cereal Chemistry, 41:173-181.

SORENSON, W.G. e C.W. HESSELTINE. 1966. Carbon and nitrogen utilization by Rhizopus oligosporus. Mycologia, 58:681689 .

STEINKRAUS, K.H. 1964. Research on Tempeh Technolagy in the United States. Japan, International Symposium on Oilseed Protein Foods. 8p.

STEINKRAUS, K.H.: C.Y. LEE e P.A. BUCK. 1965. Soybean fer mentation by the ontjom mod Neurospora. Food Technol. 19: 119-120.

STEINKRAUS, K.H.; J.P. van BUREN; L.R. HACKLER E D.B. HAND. 1965. A pilot-plant process for the production of dehy drated tempeh. Fd. Technol. 19(1):63-68.

STEINKRAUS, K.H.; Y.B. HWA; J.P. van BUREN; M.I. PROVVIDENTI e D.B. HAND. 1960. Studies on tempeh an Indonesian ferment ed soybean food. Fd. Research, 25:777-788.

TOSELLO, A. 1975. Alimentos básicos: cereais, alimentos pre vilegiados da natureza. ABIA/SAPRO, Bol. Informativo, 21: 17-32.

van BUREN, J.P.; L.R. HACKLER e K.H. STEINKRAUS. 1972. Solu bilization of soybean tempeh constituents during fermenta tion. Cereal Chem. 49 (2):208-21l. 
van BUREN, J.P.; K.H. STEINKRAUS; L.R. HACKLER; I. ELRAWI e D.B. HAND. 1964. Heat effects on soymilk. Indices of protein quality in dried soymilks. J. Agr. Fd. Chem. $12(6): 524-528$.

van VEEN, A.G.; D.C.W. GRAHAM e K.H. STEINKRAUS. 1968. Fer mented peanut press cake. Cereal Sci. Today, 13(3):96-99.

van VEEN, A.G. e G. SCHAEFER. 1950. The influence of the tempeh fungus on the soybean. Documenta Neerlandica et Morbis Tropicis, $11(3)$ : 271-281.

WANG, H.L. e C.W. HESSELTINE. 1965. Studies on the extra cellular proteolytic enzymes of Rhizopus oligosporus. Can. J. Microbiol. 11:727-732。

WAGENKNECHT, A.C.; L.R. MATTICK; L.M. LEWIN; D.B. HAND e K.H. STEINKRAUS. 1961. Changes in soybean lipids during tem peh fermentation. J.Fd. Sci. $26(4): 373-376$.

WANG, H.L. e C.W. HESSELTINE. 1966. Wheat tempeh. Cereal Chemistry. 43:563-570.

WANG, H.L.; D.I. RUTTLE e C.W. HESSELTINE. 1968. Protein quality of wheat and soybeans after Rhizopus oligosporus fermentation. J. Nutrition. 96:109-114. 